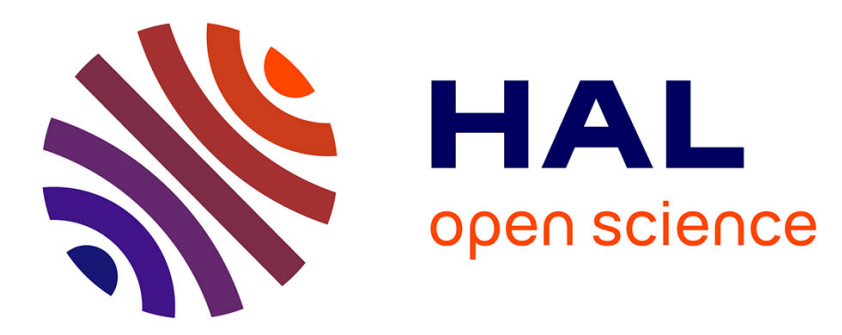

\title{
Similar hydraulic efficiency and safety across vesselless angiosperms and vessel-bearing species with scalariform perforation plates
}

\author{
Santiago Trueba, Sylvain Delzon, Sandrine Isnard, Frederic Lens
}

\section{- To cite this version:}

Santiago Trueba, Sylvain Delzon, Sandrine Isnard, Frederic Lens. Similar hydraulic efficiency and safety across vesselless angiosperms and vessel-bearing species with scalariform perforation plates. Journal of Experimental Botany, 2019, 70 (12), pp.3227-3240. 10.1093/jxb/erz133 . hal-02279487

\section{HAL Id: hal-02279487 \\ https://hal.umontpellier.fr/hal-02279487}

Submitted on 26 Jul 2021

HAL is a multi-disciplinary open access archive for the deposit and dissemination of scientific research documents, whether they are published or not. The documents may come from teaching and research institutions in France or abroad, or from public or private research centers.
L'archive ouverte pluridisciplinaire HAL, est destinée au dépôt et à la diffusion de documents scientifiques de niveau recherche, publiés ou non, émanant des établissements d'enseignement et de recherche français ou étrangers, des laboratoires publics ou privés. 


\section{Similar hydraulic efficiency and safety across vesselless angiosperms and vessel-bearing species with scalariform perforation plates}

Santiago Trueba ${ }^{1,2, *}$, Sylvain Delzon ${ }^{3}$, Sandrine Isnard $^{2}$, and Frederic Lens ${ }^{4}$

${ }^{1}$ Department of Ecology and Evolutionary Biology, University of California, Los Angeles, 621 Charles E. Young Dr. South, Los Angeles, CA 90095, USA

${ }^{2}$ AMAP, IRD, CIRAD, CNRS, INRA, Université de Montpellier, Nouméa, New Caledonia

${ }^{3}$ BIOGECO, INRA, Université de Bordeaux, Pessac 33610, France

${ }^{4}$ Naturalis Biodiversity Center, Leiden University, PO Box 9517, 2300RA Leiden, The Netherlands.

*Corresponding author: strueba@ gmail.com; +1 3104658307

\section{Highlight}

Xylem hydraulic conductivity and embolism vulnerability are similar between vesselless versus vessel-bearing angiosperm species. Significant differences in vulnerability to embolism across species are explained by interconduit pit membrane thickness.

(C) The Author(s) 2019. Published by Oxford University Press on behalf of the Society for Experimental Biology. All rights reserved. For permissions, please email: journals.permissions@oup.com 


\begin{abstract}
The evolution of xylem vessels from tracheids is put forward as a key innovation that boosted hydraulic conductivity and photosynthetic capacities in angiosperms. Yet, the role of xylem anatomy and interconduit pits on hydraulic performance across vesselless and vessel-bearing angiosperms is incompletely known, and there is a lack of functional comparisons of ultrastructural pits between species with different conduit types. We assessed xylem hydraulic conductivity and vulnerability to drought-induced embolism in 12 rain forest species from New Caledonia, including five vesselless species, and seven vessel-bearing species with scalariform perforation plates. We measured xylem conduit traits, along with ultrastructural features of the interconduit pits to assess the relationships between conduit traits and hydraulic efficiency and safety. In spite of major differences in conduit diameter, conduit density, and the presence/absence of perforation plates, the species studied showed similar hydraulic conductivity and vulnerability to drought-induced embolism, indicating functional similarity between both types of conduits. Interconduit pit membrane thickness $\left(T_{\mathrm{m}}\right)$ was the only measured anatomical feature that showed a relationship with significant vulnerability to embolism. Our results suggest that the incidence of drought on rain forest ecosystems can have similar effects on species bearing water conducting cells with different morphologies.
\end{abstract}

Keywords: drought resistance, embolism resistance, interconduit pit membrane thickness, New Caledonia, rain forest ecology, scalariform perforation plates, tracheids, vessel elements, vesselless angiosperms, wood anatomy. 


\section{Introduction}

Along with other relevant functions like mechanical support and storage of photosynthates, the major function of wood tissue is to transport water from the soil to the transpiring leaves (Badel et al., 2015). Xylem conduits (i.e. tracheary elements) comprise the water conducting cells enabling long-distance water transport in vascular plants. Structurally, xylem conduits can be divided in two types: 1) tracheids, which are single-celled water conducting units with densely pitted lateral walls and without perforations, and 2) vessels, which are multiple-celled conduits forming long hollow tubes comprised of single-celled vessel elements that are axially connected by their perforation plates (Sperry, 2003). The evolution of vessels from tracheids has been traditionally considered a major functional transition that happened several times in land plant evolution (Bailey \& Tupper, 1918), although intermediate conduit types with various degrees of pit membrane remnants in perforation plates also exist (Carlquist, 1992; Carlquist \& Schneider, 2002a). Vessels have enabled plants to develop a more efficient hydraulic pipeline compared to vesselless species, allowing higher leaf vein densities and increased photosynthetic capacities in vessel-bearing species and thereby offering greater competitive advantage over vesselless species (Bailey, 1944; Brodribb \& Feild, 2000; Brodribb \& Feild, 2010; Feild \& Wilson, 2012; Feild \& Brodribb, 2013).

Vessellessness is a rare feature in angiosperms since it is restricted to only few clades such as Acorales, Amborellales, Nymphaeales, Trochodendrales, and Winteraceae (Spicer \& Groover, 2010; Olson, 2014). Because of their structurally-driven low transpiration rates, most vesselless angiosperms and angiosperms with vessel elements having densely-barred scalariform perforation plates have likely occupied mesic habitats since their origin (Feild et al., 2003; Feild et al., 2004). For instance, the New Caledonian vesselless shrub Amborella trichopoda, which is sister to all other extant angiosperms, is mainly found in the moist understorey of rain forest environments with closed canopies and presents the architectural characteristics of a shade-adapted plant (Feild \& Arens, 2007; Trueba et al., 2016). The environmental preferences of vesselless angiosperms suggest a low adaptation to drought stress, which likely have restricted these species to humid environments. Vessel elements with oblique scalariform perforation plates bearing many bars can be considered morphologically as intermediate between tracheids and vessel elements with simple perforation plates (Carlquist \& Schneider, 2002a). Despite being derived from a tracheid-based xylem, vesselbearing species with perforation plates including many closely spaced bars are hypothesized 
to have a similar, rather inefficient, hydraulic performance compared to vesselless angiosperms due to the high flow resistance exerted by their scalariform perforation plates (Christman \& Sperry, 2010; Hudson et al., 2010; Feild et al., 2011). Moreover, it has been shown that pit membrane remnants are usually present in these types of scalariform perforations (Carlquist, 1992; Carlquist \& Schneider, 2002a; Carlquist \& Schneider, 2002b), which further impedes hydraulic performance (Feild \& Wilson, 2012). Little is known about the xylem anatomical features associated with the hydraulic performance of these species, although a recent study has shown that hydraulic vulnerability is a major driver of rain forest habitat occupation in vesselless and vessel-bearing New Caledonian angiosperms (Trueba et al., 2017).

Anatomical features such as conduit diameter and density have a direct effect on the efficiency and safety of water conductivity (Pittermann \& Sperry, 2003; Loepfe et al., 2007; Zanne et al., 2010; Gleason et al., 2016b). For instance, wide conduits reduce resistance to flow, and thus increase hydraulic efficiency (Hacke et al., 2006; Hacke et al., 2017). Yet, it has been proposed that vesselless angiosperms do not show a significant increase in flow conductivity with increasing conduit diameter (Hacke et al., 2007). Because hydraulic conductivity efficiency is proportional to the sum of the conduit diameters to the fourth power according to the Poiseuille's law (Tyree \& Zimmermann, 2002), it is possible to estimate theoretical hydraulic conductivity using anatomical variables. However, no study to date has carried out a comparison of theoretical and native hydraulic conductivity across vesselless and vessel-bearing angiosperms with scalariform perforation plates. Along with transport efficiency, hydraulic safety is also an important feature that is influenced by wood anatomical features (Lens et al., 2011; Li et al., 2016). Safety in water transport reflects the ability of plants to cope with high xylem tensions within the conduits, which could lead to a partial airfilled blockage of the water transport pathway due to drought-induced embolism formation. In theory, after embolism occurrence, species with wider and less numerous conduits should be more affected because greater conductive surfaces are impacted. In addition to conduit diameter and density, the ratio between the thickness $(t)$ of two adjacent conduit walls and the conduit lumen diameter $(b)$ has been proposed to relate to xylem embolism resistance by providing a mechanical reinforcement of conduit walls acting as a safety factor from potential implosion by negative pressure (Hacke et al., 2001; Jacobsen et al., 2005). As an example, tracheid wall thickness has been shown as an important functional trait in the earlywood of 
conifers (Rosner et al., 2018), as well as the thickness-to-diameter ratio in the leaf vasculature (Jordan et al., 2013).

Since both tracheids and vessels are limited in length, and are always much shorter than the size of the entire plant, both tracheids and vessels have bordered interconduit pits in their lateral walls through which water can be laterally transported from one conduit to an adjacent conduit (Sano et al., 2011; Lens et al., 2013). Fine-scale features of these interconduit pits, especially those related to the pit membrane, have been demonstrated to play a major role in avoiding air bubble propagation throughout the $3 \mathrm{D}$ conduit network and thereby contributing to embolism resistance in angiosperms, gymnosperms and pteridophytes (Choat et al., 2008; Delzon et al., 2010; Pittermann et al., 2010; Lens et al., 2011; Brodersen et al., 2014; Schenk et al., 2015; Li et al., 2016). Bordered pit features conferring embolism resistance have been analyzed in conifer tracheids, showing the main role of the overlap between torus and pit aperture (Delzon et al., 2010; Bouche et al., 2014). However, tracheids in vesselless angiosperms have homogenous pit membranes that are devoid of the torusmargo structure. The thickness of the pit membrane $\left(T_{\mathrm{m}}\right)$ has been suggested to be a major determinant of embolism resistance in angiosperm vessels (Lens et al., 2011; Li et al., 2016; Dória et al., 2018). Thicker $T_{\mathrm{m}}$ increase the tortuous path length that air needs to cross before reaching an adjacent water-filled conduit, therefore impeding air-seeding between adjacent conduits, and this mechanism could explain the direct functional link between $T_{\mathrm{m}}$ and embolism resistance (Jansen et al., 2009; Lens et al., 2013; Li et al., 2016). Given that air bubble expansion occurs immediately after air entry through a pit membrane, the most likely space for air bubble expansion is within the limits of the pit borders (Schenk et al., 2015). Accordingly, pit chamber depth $\left(L_{\mathrm{p}}\right)$, which is the distance between the roof of the pit border and the position of the relaxed pit membrane, has been also suggested as being related with embolism resistance in angiosperm vessels (Lens et al., 2011).

A recent study analyzed the relationship between the xylem pressure inducing $50 \%$ loss of xylem hydraulic conductivity $\left(P_{50}\right)$ and intertracheid pit structure in six vesselless angiosperm species, showing a lack of correlation between $P_{50}$ and $T_{\mathrm{m}}$ (Zhang et al., 2017). Yet, the study of Zhang et al. (2017) used $P_{50}$ values collected from the literature, and did not include anatomical measurements from the same individuals for which the hydraulic data were generated. Here, we assess these structure-function correlations using data from same individuals, and we include vesselless and vessel-bearing species with scalariform perforation 
plates inhabiting a similar rain forest ecosystem. Moreover, with the exception of Amborella trichopoda, we investigate species that have not been included in previous studies.

In this study, we analyze xylem hydraulic efficiency vs. safety along with stem anatomical features (Table 1), with a special focus on fine-scale observations of interconduit pits in vesselless and vessel-bearing species native to the New Caledonian rain forests. We aim to test the hypotheses that: i) vessel-bearing species with scalariform perforation plates show similar hydraulic conductivity and vulnerability to embolism than vesselless species occurring in the same environment; ii) the diameter, density, and wall structure of xylem conduits are associated to xylem hydraulics, with species having wider conduits with proportionally thinner walls being hydraulically more efficient but also more vulnerable; and iii) ultrastructural variation in the thickness of interconduit pits of both vesselless and vesselbearing species is functionally linked with vulnerability to embolism. Analyzing vesselless and vessel-bearing species with putative ancestral features such as scalariform perforation plates helps our understanding of the early stages of the hydraulic evolution in flowering plants. Finally, we provide meaningful information regarding the mechanisms that confer drought tolerance in a unique tropical island ecosystem that can be threatened by deficits in rainfall regimes.

\section{Materials and Methods}

\section{Plant material and sampling}

Twelve woody species endemic to New Caledonia were studied (Table 2). All studied species are evergreen and have diffuse-porous wood without growth ring boundaries. Among the studied species, seven are vessel-bearing and have vessel elements with long and obliquely oriented scalariform perforation plates (Table 2). Vessel-bearing species belong to the families Atherospermataceae, Chloranthaceae, Monimiaceae, and Paracryphiaceae. The five studied vesselless species belong to the Amborellaceae and the Winteraceae, which are the only families of vesselless angiosperms present in the New Caledonian archipelago. The woody growth forms of the sampled species vary from shrubs such as Amborella trichopoda and Ascarina rubricaulis, to trees such as Nemuaron viellardii and Hedycarya parvifolia. All studied species are present in rain forest ecosystems. However, they differ in their percentage of rainforest occupancy (Pouteau et al., 2015). 15 terminal and sun-exposed branches per species were collected at predawn from three individuals. Branches were defoliated, wrapped in moist paper towels with ultrapure water and sealed in dark plastic bags during transport. 


\section{Xylem hydraulic conductivity and embolism vulnerability}

Hydraulic measurements of sampled branches were carried out in the plant hydraulics phenotyping platform of the BIOGECO laboratory in Pessac, France. Samples were stored at $5^{\circ} \mathrm{C}$ before transportation, and measurements were done within two weeks after collection. We verified the absence of pathogens before performing measurements. Branches were excised under water to $27 \mathrm{~cm}$ segments. Both ends of the branches were debarked and clipped with a fresh razor blade. The embolism vulnerability of branch segments was then measured using the Cavitron technique (Cochard et al., 2005), which uses centrifugal forces to lower the xylem pressure while simultaneously measuring hydraulic conductivity. This allowed us to measure xylem specific hydraulic conductivity $\left(K_{\mathrm{s}}\right.$, in $\left.\mathrm{kg} \mathrm{m}^{-1} \mathrm{MPa}^{-1} \mathrm{~s}^{-1}\right)$ using the maximum measured conductivity divided by sample length and sapwood area as averaged from both ends of the sample. Percentage losses of hydraulic conductivity for the analyzed species were obtained from a previous study (Trueba et al., 2017). The vulnerability curves included in this study were reassessed fitting the Weibull function proposed by Ogle et al. (2009), which was implemented using the R package 'fitplrc' (Duursma \& Choat, 2017). $P_{50}$, the xylem pressure inducing a $50 \%$ loss of hydraulic conductivity and $S_{50}$, the slope of the curve at $P_{50}$, which relates to the speed of xylem embolism propagation, were calculated from the vulnerability curves built using the Weibull function. In addition to $P_{50}$, which is the most commonly used index of embolism resistance (Choat et al., 2012), we also extracted $P_{12} . P_{12}$ is the xylem pressure inducing a $12 \%$ loss of hydraulic conductivity, which corresponds to the point of airentry according to Domec and Gartner (2001) and Martin-StPaul et al. (2017). Mean water potentials inducing loss of stem hydraulic conductivity and their corresponding slope values were calculated from six to 11 samples per species.

\section{Xylem conduit measurements and analyses}

Wood cubes of $c .10 \mathrm{~mm}^{2}$ were sampled from two branches used for the hydraulic measurements. Transverse sections 30-50 $\mu$ m thick were made using a sliding microtome. After sectioning, sections were treated with sodium hypochlorite and stained with $0.1 \%$ toluidine blue aqueous solution for 5-10 min. In parallel, a mixture of safranin and alcian blue (35:65) was also used for tissue staining. Stained sections were suspended in the mounting 
medium Euparal (Waldeck GmbH \& Co, Münster, Germany) and mounted on microscope slides for imaging. Cross-section images were done using a light microscope equipped with a digital camera (Leica DM5000B; Leica Microsystems, Wetzlar, Germany). Images were carried out at five random positions of the mounted wood sections. All anatomical measurements on digital images were carried out using ImageJ 1.50v (National Institutes of Health, Bethesda, USA). Measurements were carried out on 25 randomly selected conduits per sample, resulting in 50 xylem conduits measured per species. We measured the inner lumen area of xylem conduits and conduit diameter was derived from this measurement assuming a circular shape. The hydraulically weighted conduit diameter $\left(D_{\mathrm{H}}\right)$, which corresponds to the mean diameter required to achieve equal conductivity with the same number of conductive elements, was calculated according to Tyree and Zimmermann (2002) using the equation:

$$
D_{\mathrm{H}}=\left[\frac{\sum D^{4}}{N}\right]^{0.25}
$$

where $D$ is the diameter of an individual conduit and $N$ is the number of conduits measured. Conduit density $\left(\mathrm{CD}, \mathrm{n} \mathrm{mm}^{-2}\right.$ ) was estimated in four randomly selected $0.25 \mathrm{~mm}^{2}$ images per sample. CD was calculated as the outcome of the number of conduits per square millimeter. Both $D_{\mathrm{H}}$ and CD were used to estimate the xylem specific theoretical hydraulic conductivity $\left(K_{\mathrm{th}}, \mathrm{kg} \mathrm{m}^{-1} \mathrm{MPa}^{-1} \mathrm{~s}^{-1}\right)$ also known as potential conductivity (Fichot et al., 2010; Poorter et al., 2010). In spite of the potential presence of both tracheids and vessels in the xylem of some vessel-bearing species, only the vessels, which were considered as the main water conducting cells, were considered for $K_{\text {th }}$ estimations. $K_{\text {th }}$ was calculated based upon the Hagen-Poiseuille law using the equation:

$$
K_{\mathrm{th}}=\frac{\pi \rho_{\mathrm{w}}}{128 \eta} \times \mathrm{CD} \times D_{H}^{4}
$$

where $\rho_{\mathrm{w}}$ is the density of water at $20^{\circ} \mathrm{C}\left(998.2 \mathrm{~kg} \mathrm{~m}^{-3}\right)$ and $\eta$ is the viscosity of water at $20^{\circ} \mathrm{C}$ $\left(1.002 \times 10^{-9} \mathrm{MPa}\right)$. Measurements of the double thickness of two adjacent conduits $\left(T_{\mathrm{w}}\right.$, $\mu \mathrm{m})$ were carried out to estimate xylem conduit wall reinforcement enabling conduit implosion resistance (Hacke et al., 2001). The index of safety from implosion by negative pressure was estimated as $(t / b)^{2}$, where $t$ is the thickness of two adjacent conduit walls and $b$ is the conduit lumen diameter. 


\section{Xylem conduit ultrastructure and lateral pit anatomical measurements}

We measured ultrastructural traits of interconduit pits using images obtained from transmission electron microscopy (TEM). For TEM imaging, wood samples from the fresh branches used for the Cavitron experiments were cut into $c .2 \mathrm{~mm}^{3}$ blocks and fixed in Karnovsky solution containing formaldehyde and glutaraldehyde (Karnovsky, 1965). Samples were then rinsed using a $0.1 \mathrm{M}$ cacodylate buffer and postfixed with $2 \%$ osmium tetroxide for $2 \mathrm{~h}$. Samples were gradually dehydrated using increasing propanol concentrations.

Subsequently, samples were embedded using Epon 812n (Electron Microscopy Sciences, Hatfield, UK) and polymerized at $60{ }^{\circ} \mathrm{C}$ for $48 \mathrm{~h}$. Embedded samples were sectioned into 2 $\mu \mathrm{m}$ thick transverse sections. Sections were examined to detect areas of contact between conduits (vessel-vessel or tracheid-tracheid). After trimming, these areas were re-cut into 90 $\mathrm{nm}$ thick transverse sections using a diamond knife. The sections were coated on copper grids using Formvar coating (Agar Scientific, Stansted, UK). TEM micrographs were made using a JEM 1400-Plus TEM (JEOL, Tokyo, Japan). Lateral pit ultrastructural characteristics were measured following the protocols described by Scholz et al. (2013). Given that we discarded images with visually damaged pit membranes or with insufficient contrast, the number of measurements per species varied depending on the amount of quality micrographs. More than 25 observations were made for most species except Hedycarya parvifolia (17 obs), Zygogynum crassifolium (15 obs), and Z. tieghemii (19 obs). Pit membrane thickness $\left(T_{\mathrm{m}}, \mathrm{nm}\right)$ was measured at one point near the center of the pit membrane. Pit chamber depth $\left(L_{\mathrm{p}}, \mathrm{nm}\right)$ was measured as the distance from the roof of the pit border (close to the aperture) to the relaxed position of the pit membrane. Pit aperture diameter $\left(D_{\mathrm{pa}}, \mu \mathrm{m}\right)$ and pit membrane diameter $\left(D_{m}, \mu \mathrm{m}\right)$ were also measured in TEM images. TEM imaging was done on fresh material to avoid potential thickness underestimations derived from the desiccation and alteration of pit membrane structural properties (Scholz et al., 2013; Li et al., 2016; Zhang et al., 2017). We also used SEM micrographs to observe qualitative features of xylem conduits and perforation plate morphology in radial segments. SEM micrographs were acquired using a desktop SEM Phenom G2 Pro (Phenom-World BV, Netherlands) with magnifications between $x 1500$ and $\times 20000$, and an acceleration voltage of $5 \mathrm{kV}$.

\section{Statistical and phylogenetic analyses}

Hydraulic and anatomical traits were assembled and averaged for each species for data analysis. For each trait, assumptions of residual homogeneity and normality were tested prior to analysis. We explored relationships between anatomical traits across species using pairwise 
Pearson's correlation analyses and regression analyses. Linear regression analyses were used to determine the influence of anatomical variables on the hydraulic performance and the species vulnerability to embolism. Given that inferences about the adaptive value of correlations obtained from standard methods can be biased by the potential affinity of closely related species (Felsenstein, 1985), we analyzed trait correlations using phylogenetically independent contrast (PIC) correlations using the R package 'ape' (Paradis et al., 2004). We built a phylogenetic tree using as a backbone the phylogeny of seed plants available in Smith and Brown (2018), which includes a branch length calibration based on Magallón et al. (2015). Molecular data was available for nine out of the 12 studied species. We used the package 'ape' to trim the tree and select the species studied. The species included in the tree were Amborella trichopoda, Ascarina rubricaulis, Hedycarya cupulata, H. parvifolia, Kibaropsis caledonica, Paracryphia alticola, Zygogynum acsmithii, Z. crassifolium, and Z. thieghemii (see Fig. S1 available online as Supporting Information).

To assess the relationship between theoretical and measured hydraulic conductivity, given these relationship holds between two "dependent" variables, we fitted a standardized major axis (SMA) regression using the R package 'smatr' (Warton et al., 2012). Additionally, we employed one-way ANOVAs to assess trait variability across species. To explore the effect of lateral pit aperture ultrastructure on embolism resistance, we analyzed a possible joint effect of $L_{\mathrm{p}}$ and $T_{\mathrm{m}}$, two traits that have been reported as having an important role on embolism resistance (Lens et al., 2011), on embolism resistance thresholds $\left(P_{12}\right.$ and $\left.P_{50}\right)$. We performed multiple regression analyses, and the strength of the contribution of each ultrastructural trait to embolism resistance was evaluated using semipartial correlations. Xylem hydraulic and anatomical traits of vesselless and vessel-bearing angiosperms were compared using independent-samples $t$-tests. All the analyses were considered significant at $P$ $\leq$ 0.05. All statistical analyses were performed using R v.3.4.1 (R Core Team, 2017).

\section{Results}

\section{Xylem conduit density, diameter, and wall thickness}

Vesselless and vessel-bearing species differed significantly in $D_{\mathrm{H}}$ and CD (Fig. 1; Table 3). $D_{\mathrm{H}}$ ranged from $19.77 \pm 0.5 \mu \mathrm{m}$ (mean $\pm \mathrm{SE}$ ) in the tracheid-bearing Zygogynum crassifolium, to $45.17 \pm 1.49 \mu \mathrm{m}$ in the vessel-bearing Ascarinia rubricaulis (Table 2). Average tracheid $D_{\mathrm{H}}$ across vesselless species was $22.60 \pm 0.98 \mu \mathrm{m}$, and average vessel $D_{\mathrm{H}}$ 
across vessel-bearing species was $38.45 \pm 1.98 \mu \mathrm{m}$. CD varied widely across species $(\mathrm{F}(11)=$ 199; $P \leq 0.001)$. CD ranged from $136 \pm 10$ conduits $\mathrm{mm}^{2}$ to $1229 \pm 49$ conduits per $\mathrm{mm}^{2}$, measured in Paracryphia alticola and Amborella trichopoda, respectively. Xylem conduit wall reinforcement, $(t / b)^{2}$, presented significant variation both across species $(\mathrm{F}(11)=66.79 ; P$ $\leq 0.001$ ) and across conduit types (Table 3). Vesselless species showed significant higher $(t / b)^{2}$ than vessel-bearing species (Fig. 2a; Table 3). Highest wall reinforcement was observed in vesselless species such as $Z$. thieghemii and $Z$. crassifolium with $(t / b)^{2}$ values of $0.46 \pm$ 0.039 and $0.55 \pm 0.040$, respectively. Average $T_{\mathrm{w}}$ of vesselless species was $10.36 \pm 1.48 \mu \mathrm{m}$, and average $T_{\mathrm{w}}$ of vessel-bearing species was $7.03 \pm 0.47 \mu \mathrm{m} . T_{\mathrm{w}}$ varied widely across species $(\mathrm{F}(11)=73.34 ; P \leq 0.001)$. However, there were no significant differences in $T_{\mathrm{w}}$ between vascular types.

\section{Interconduit pit ultrastructure}

$T_{\mathrm{m}}$ varied significantly across species $(\mathrm{F}(12)=29.94 ; P \leq 0.001)$ from a minimum of $169 \pm 8$ $\mathrm{nm}$ in the vessel-bearing Paracryphia alticola to a maximum of $388 \pm 26 \mathrm{~nm}$ in the vesselbearing Hedycarya parvifolia. Mean $T_{\mathrm{m}}$ in vesselless species was $258 \pm 12 \mathrm{~nm}$, which was not significantly different to the mean $T_{\mathrm{m}}$ in vessel-bearing species (266 $\pm 30 \mathrm{~nm}$; Fig. 2b; Table 3). $L_{\mathrm{p}}$ also varied significantly across species $(\mathrm{F}(11)=26.4 ; P \leq 0.001)$ from $694 \pm 42 \mathrm{~nm}$ in $P$. alticola to $1289 \pm 91 \mathrm{~nm}$ in Zygogynum thieghemii. Vesselless species had a mean $L_{\mathrm{p}}$ of $1084 \pm 80 \mathrm{~nm}$, similar to the mean $L_{\mathrm{p}}$ in vessel-bearing species (980 $\pm 70 \mathrm{~nm}$; Table 3$)$. The other two interconduit pit traits measured, $D_{\mathrm{pa}}$ and $D_{\mathrm{m}}$, had significant variation across species $\left(\mathrm{F}(11)=25.97 ; P \leq 0.001\right.$; and $\mathrm{F}(11)=9.01 ; P \leq 0.001$; respectively). $D_{\mathrm{pa}}$ varied from $1.42 \pm$ $0.11 \mu \mathrm{m}$ to $6.83 \pm 0.58 \mu \mathrm{m}$, measured in Zygogynum acsmithii and Ascarina rubricaulis, respectively. $D_{\mathrm{m}}$ ranged from $5.76 \pm 0.81 \mu \mathrm{m}$ to $11.71 \pm 0.68 \mu \mathrm{m}$, measured in Quintinia major and A. rubricaulis, respectively. Both lateral wall pit traits were not significantly different between vessel-bearing and vesselless species (Table 3).

\section{Hydraulic conductivity and drought-induced vulnerability to embolism}

$K_{\text {th }}$ varied from $2.73 \mathrm{~kg} \mathrm{~m}^{-1} \mathrm{MPa}^{-1} \mathrm{~s}^{-1}$ in the vessel-bearing Paracryphia alticola, which is theoretically the least conductive efficient species, to $24.12 \mathrm{~kg} \mathrm{~m}^{-1} \mathrm{MPa}^{-1} \mathrm{~s}^{-1}$ in the vesselbearing Ascarina rubricaulis, which was the most conductive efficient species according to estimations based on anatomical measurements. $K_{\mathrm{th}}$ did not significantly differ in species with different vascular types $(P=0.153)$ : average $K_{\text {th }}$ was $7.26 \pm 1.29 \mathrm{~kg} \mathrm{~m}^{-1} \mathrm{MPa}^{-1} \mathrm{~s}^{-1}$ in vesselless species and $12.58 \pm 3.1 \mathrm{~kg} \mathrm{~m}^{-1} \mathrm{MPa}^{-1} \mathrm{~s}^{-1}$ in vessel-bearing species (Fig. 2c; Table 3). 
Similarly, measured stem hydraulic conductivity $\left(K_{\mathrm{s}}\right)$ did not differ between vesselless and vessel-bearing species $(P=0.300 ;$ Fig. $2 \mathrm{~d}$; Table 3$) . K_{\mathrm{s}}$ and $K_{\mathrm{th}}$ had a significant correlation (Fig. 3). $K_{\mathrm{s}}$ ranged from $0.104 \mathrm{~kg} \mathrm{~m}^{-1} \mathrm{MPa}^{-1} \mathrm{~s}^{-1}$ in Hedycarya cupulata to $0.890 \mathrm{~kg} \mathrm{~m}^{-1} \mathrm{MPa}^{-1}$ $\mathrm{s}^{-1}$ in A. rubricaulis, both species have vessel-bearing xylem.

Xylem vulnerability to embolism was not significantly different between conduit types: vesselless species had a mean $P_{50}$ of $-2.85 \pm 0.32 \mathrm{MPa}$, and vessel-bearing species showed a similar mean $P_{50}$ of $-2.55 \pm 0.17 \mathrm{MPa}$ (Fig. 2f; Table 3). Average $P_{50}$ ranged from 4.11 MPa in the tracheid-bearing Zygogynum crassifolium to -2.02 MPa in the vessel-bearing Paracryphia alticola, the most vulnerable species to drought-induced xylem embolism in our dataset (Fig. 4). $P_{12}$ was also not significantly different between conduit types: vesselless species had a mean $P_{12}$ of $-2.30 \pm 0.55 \mathrm{MPa}$, and vessel-bearing species had a mean $P_{12}$ of $1.46 \pm 0.73 \mathrm{MPa}$ (Table 3). Average $P_{12}$ ranged from $-3.50 \mathrm{MPa}$ in the tracheid-bearing Zygogynum crassifolium to $-0.77 \mathrm{MPa}$ in the vessel-bearing Paracryphia alticola.

Interestingly, regardless of the xylem embolism index considered both species were the most and the least resistant species, respectively (Table 2). $P_{50}$ and $P_{12}$ were not significantly related with hydraulic efficiency, as expressed by $K_{\text {th }}$ and $K_{\mathrm{s}}$ (Table 4). $S_{50}$ varied from $24 \%$ in $H$. cupulata to a steep slope of $162 \%$ in Zygogynum acsmithii. Vesselless species had a significantly steeper slope than vessel-bearing species (Fig. 2e; Table 3).

\section{Relationships between xylem hydraulics and anatomical traits}

Among the anatomical variables measured in this study, only $T_{\mathrm{m}}$ was significantly related to significant vulnerability to drought-induced embolism, as represented by $P_{50}$ (Fig. 5a; Table 4): species with thicker pit membranes were less vulnerable to xylem embolism (Fig. 6). The relationship between $T_{\mathrm{m}}$ and $P_{50}$ was highly significant when considering only vessel-bearing species (Fig. 5a), but not significant when only considering vesselless species (Fig. 5a) mainly because of the effect of $Z$. crassifolium, an outlier which had relatively thin interconduit pit membranes with respect to its high embolism resistance. We did not observe a significant relationship between $T_{\mathrm{m}}$ and $P_{12}$, the second index of embolism vulnerability included in this study (Table 4). Other ultrastructural pit features such as $D_{\mathrm{pa}}, D_{\mathrm{m}}$, and $L_{\mathrm{p}}$ were not related to $P_{50}$ (Fig. 5b; Table 4). However, $P_{12}$ was correlated with anatomical features such as CD, $(t / b)^{2}, L_{\mathrm{p}}$, and $T_{\mathrm{w}}$ (Table 4). Multiple regression analyses including the joint effect of $L_{\mathrm{p}}$ and $T_{\mathrm{m}}$ on xylem embolism vulnerability showed a non-significant variation of $P_{12}$ and $P_{50}$ (Table $\mathrm{S} 1$ ). The coefficients associated with $L_{\mathrm{p}}$ or $T_{\mathrm{m}}$ were not significant in both models (Table 
$\mathrm{S} 1)$. However, $L_{\mathrm{p}}$ was the variable that contributed the most to $P_{12}$ variation, and $T_{\mathrm{m}}$ was the variable that contributed the most to $P_{50}$ variation, as shown by the higher semipartial correlation values (Table S1). The lower association of $P_{50}$ with $L_{\mathrm{p}}$ was readily observed using ordinary least square regressions (Fig. 5b).

Furthermore, we observed a significant relation of $S_{50}$ and $(t / b)^{2}$ with $\mathrm{CD}$, and a positive correlation between $D_{\mathrm{pa}}$ and $D_{\mathrm{H}}$ with $K_{\mathrm{th}}$. We found less significant inter-trait correlations after phylogenetic corrections (Table 4). This might result from a more limited correlated evolution between traits, and because of the lower number of species considered in the analysis. Significant Pearson and PIC correlations were observed between anatomical features such as $L_{\mathrm{p}}$ and $T_{\mathrm{w}}$. Moreover, the relations of CD with $S_{50}$, and $D_{\mathrm{H}}$ with $K_{\mathrm{th}}$ remained significant after phylogenetic correction. A complete list of coefficients of Pearson $(r)$ and phylogenetic independent contrast correlations $\left(r_{\mathrm{PIC}}\right)$ between hydraulic and anatomical traits across species is available in Table 4.

\section{Discussion}

\section{Similar hydraulic efficiency and safety in stems of vesselless and vessel-bearing angiosperms with scalariform perforation plates}

Vesselless and vessel-bearing angiosperm species with scalariform perforation plates had similar hydraulic performance when considering both measured $\left(K_{\mathrm{s}}\right)$ and theoretical $\left(K_{\mathrm{th}}\right)$ xylem specific hydraulic conductivity (Fig. 2, Table 3), confirming previous observations at the sapwood level (Sperry et al., 2007; Hacke et al., 2007; Hudson et al., 2010). Based on the tight relation between $K_{\text {th }}$ and $K_{\mathrm{s}}$, we obtained a satisfactory prediction of stem hydraulic conductivity using xylem anatomical measurements regardless of the xylem conduit type. The higher rates of $K_{\mathrm{th}}$, as compared to $K_{\mathrm{s}}$, arise from the underestimation of a number of structural features that can exert additional resistance to flow such as perforation plate morphology and ultrastructural interconduit pit variation (Sperry et al., 2007; Christman \& Sperry, 2010; Hacke et al., 2017). For instance, single-vessel flow measurements have demonstrated that scalariform perforation plates contribute significantly to the resistance to water flow, presenting 580\% higher resistance at the sapwood level compared to species with vessels bearing simple perforation plates (Christman \& Sperry, 2010). Moreover, interconduit pits account for more than $50 \%$ of total xylem hydraulic resistance in angiosperms (Sperry et al., 2006; Choat et al., 2008), mainly caused by the thickness of the pit membranes and the 
diameters of the pit apertures, emphasizing the strong influence of pit-level ultrastructural differences on hydraulic conductivity.

Only two vessel-bearing species, Ascarina rubricaulis and Nemuaron viellardii, had higher $K_{\mathrm{s}}$ values than the vesselless species studied. Interestingly, A. rubricaulis and $N$. viellardii were the studied species with the highest average $D_{\mathrm{H}}$ measured, illustrating the relevance of conduit diameter in increasing hydraulic conductivity. The low $K_{\mathrm{s}}$ values measured in the remaining vessel-bearing species likely result from the morphology of their perforation plates, since they all present oblique scalariform perforation plates with numerous, closely spaced bars (often more than 20; Fig. 7a,b). Paracryphia alticola, one of the species with the lowest $K_{\mathrm{s}}$ measured (Table 2) is noteworthy in this regard because of the exceptionally high number of bars per perforation plate (on average more than 100, with maximum values of up to 200 according to Dickison and Baas (1977); Fig. 7b). The observed similarities in hydraulic efficiency across vesselless and vessel-bearing angiosperms with scalariform perforation plates underpin the view that efficient vessel-bearing species emerged only after the reduction of bars in the scalariform perforation plates and the development of highly efficient simple perforation plates in which all the bars have disappeared. It has been shown that the tracheids of vesselless angiosperms have a lower pit area resistivity in comparison to those of eudicot vessels (Hacke et al., 2007). However, Sperry et al. (2007) estimated that the more efficient eudicot angiosperms, which are overrepresented by species with simple perforation plates, have about 4.5 times lower sapwood-specific resistivity than early diverging angiosperms including both vessel-bearing and vesselless lineages.

Along with perforation plate morphology, it has been suggested that pit membrane remnants further increase sap flow resistivity (Carlquist, 1992; Sperry et al., 2007; Feild \& Wilson, 2012). Pit membrane remnants, observed in the scalariform perforation plates of the species studied here (Fig. 7c,d), are considered to be a relictual character in angiosperms and are regularly observed in angiosperm species with densely-barred scalariform perforation plates (Carlquist, 1992; Carlquist \& Schneider, 2004). Incomplete lysis of the cellulose microfibrils in developing scalariform perforation plates causes this transitional stage between tracheids (with intact pit membranes in scalariform end wall pitting) and vessel elements (with none or residual pit membrane remnants in the scalariform perforation plates; Carlquist, 1992). Taken all together, scalariform perforation plates with many bars and pit membrane 
remnants represent major obstructions to flow, accounting to $57 \%$ of the total flow resistivity on average (Sperry et al., 2007).

In addition to the comparable hydraulic efficiency between the vesselless and vesselbearing angiosperm species studied, our observations also showed no differences in vulnerability to xylem embolism $\left(P_{12}\right.$ and $\left.P_{50}\right)$ between both groups. The similar low efficiency and safety in xylem hydraulic transport observed here in both groups supports the hypothesis that early diverging angiosperms were limited to mesic habitats with low evaporative demands and low drought-induced embolism resistance throughout their evolutionary history (Sperry et al., 2007; Carlquist, 2012; Feild \& Wilson, 2012). On the other hand, species with different conduit types showed significant differences in $S_{50}$ obtained from vulnerability curves fitted using a Weibull function, suggesting that the drought-induced loss in hydraulic conductivity occurs faster in vesselless species. This difference in speed of hydraulic dysfunction between vessel-bearing and vesselless species may be caused by the higher conduit density of vesselless species, and thus more numerous pit connections between tracheids that enable air to propagate faster within the 3D tracheid network. We did not find a clear safety-efficiency tradeoff in our dataset, which is in line with the weak relation between xylem hydraulic safety and efficiency observed in woody species across different ecosystems (Gleason et al., 2016a).

\section{Anatomical features conferring embolism resistance in angiosperms with different xylem conduit morphologies: the key role of interconduit pit membrane thickness.}

Our study highlights that pit structural traits are the most important anatomical feature in determining xylem embolism resistance. Indeed, among all measured xylem conduit features, interconduit pit membrane thickness $\left(T_{\mathrm{m}}\right)$ was the only trait that was significantly linked to significant levels of embolism resistance $\left(P_{50}\right)$. Overall, species with thicker interconduit pit membranes showed higher resistance to drought-induced embolism formation, which is in agreement with previous studies across a diversity of angiosperm species (Lens et al., 2011; Li et al., 2016; Dória et al., 2018; Dória et al., 2019). Due to the accumulation of cellulose microfibril layers in the interconduit pit membranes, species with thicker pit membranes have a longer and more tortuous pathway for air bubbles to traverse from an embolized conduit to an adjacent water-filled conduit. Moreover, it is believed that thicker interconduit pit membranes have more lipid-based surfactants molecules in the intervessel pit membranes, which may facilitate coating of the nano-scaled air bubbles, 
thereby stabilizing these nanobubbles under negative pressure (Schenk et al., 2015; Schenk et $a l ., 2016)$. Additionally, higher $T_{\mathrm{m}}$ might allow for safeguarding the mechanical integrity at high cavitation-inducing tensions (Tixier et al., 2014), thereby preventing the pores in the pit membranes to enlarge above a critical air-seeding threshold.

The relation between $T_{\mathrm{m}}$ and $P_{50}$ was not significant when considering vesselless species only. The lack of $T_{\mathrm{m}}-P_{50}$ correlation observed in the vesselless angiosperms studied might stem from a low variation in embolism vulnerability thresholds. However, our results matching anatomical and hydraulic observations from the same stems - are consistent with a recent study that could not detect a functional $T_{\mathrm{m}}-P_{50}$ correlation in six vesselless angiosperm species based on anatomical and hydraulic observations that came from different individuals (Zhang et al., 2017; see Table S2). When merging our data with the Zhang et al. (2017) dataset, we were still unable to detect a significant correlation between $T_{\mathrm{m}}-P_{50}$ amongst the vesselless species $(r=-0.27 ; P=0.45$; Fig. S2). Future studies with a denser sampling, combining hydraulic and anatomical measurements from the same individuals, are necessary to further explore the relation between $T_{\mathrm{m}}$ and $P_{50}$ in vesselless angiosperm species. The lack of PIC correlations observed between $T_{\mathrm{m}}$ and $P_{50}$ suggests that the evolutionary basis for a coordination between pit membrane thickness and increased embolism resistance is weak. However, this analysis was performed on only nine out of the 12 species measured due to incomplete sampling in published molecular phylogenies. Future studies including phylogenetic corrections would be needed to understand the evolutionary significance of xylem conduit ultrastructural variation, and its link to embolism resistance in the plant hydraulic system.

Conduit diameter was not related to drought-induced embolism vulnerability in our study. This is in accordance with Tyree and Sperry (1989) who argued that the mechanism of embolism formation is not directly linked to conduit diameter. The relation between droughtinducing embolism and $D_{\mathrm{H}}$ is controversial: large trees tend to be more prone to droughtinduced mortality compared to shorter trees (Bennett et al., 2015) probably because plant size being the main driver of conduit diameter variation (Olson et al., 2018), but sound evidence for this correlation at the high (Hacke et al., 2017) or low taxonomic level (Fichot et al., 2010; Lens et al., 2011) is ambiguous. Our results in branches of comparable diameter and position in the crown suggest that conduit diameter and embolism vulnerability are unrelated across angiosperms with different conduit morphologies. Likewise, we did not find a 
significant relation between conduit density (CD) and $P_{50}$, and species with different types of tracheary elements showed similar embolism-inducing pressure thresholds. Nevertheless, CD was significantly correlated to $S_{50}$ across species, and this relation was also significant using PIC correlation analyses. The relation between $\mathrm{CD}$ and $S_{50}$ suggests that tracheid-bearing species with numerous adjacent conduits per xylem surface area have a faster propagation of embolisms via air-seeding compared to vessel-bearing species with fewer conduits. $P_{12}$, which has been suggested as an air-entry threshold (Domec \& Gartner, 2001; Martin-StPaul et al., 2017), was correlated to CD, $L_{\mathrm{p}}, T_{\mathrm{w}}$, and $(t / b)^{2}$. Moreover, the pit chamber depth $\left(L_{\mathrm{p}}\right)$ showed a higher semipartial correlation value than pit membrane thickness $\left(T_{\mathrm{m}}\right)$ when explaining the joint effect of both structural features on $P_{12}$. These results suggest an important role of conduit wall features and pit chamber depth on air propagation under low xylem tensions.

One of the features that diverged between vesselless and vessel-bearing species was cell wall reinforcement or thickness-to span ratio of conduits, as represented by $(t / b)^{2}$. A similar index, $(t / b)^{3}$, has been shown to be significantly related to climate variables and leaf $P_{50}$ in Australian angiosperms (Blackman et al., 2010; Jordan et al., 2013). Yet, conduit wall reinforcement was unrelated to embolism vulnerability in our set of species: vesselless species presented significantly higher $(t / b)^{2}$ than vessel-bearing species, but both groups showed similar embolism vulnerability values. Therefore, it seems that conduit wall reinforcement is not selected for moist rainforest habitats, as opposed to the strong relationship of $(t / b)^{2}$ vs $P_{50}$ in drier vegetation types such as southern Californian chaparral (Jacobsen et al., 2005). Additionally, tracheids are simultaneously involved in the mechanic and hydraulic functions of vesselless angiosperms (Hudson et al., 2010; Feild \& Wilson, 2012; Feild et al., 2012). Therefore, the higher conduit wall reinforcement in vesselless angiosperms might be selected to meet the mechanical demands of the stems, blurring the relation between $(t / b)^{2}$ and $P_{50}$. $(t / b)^{2}$ was however related to $P_{12}$, suggesting an important role of conduit wall reinforcement during the onset of xylem embolism formation.

\section{New Caledonian rain forests, a safe haven for species with inefficient and drought- sensitive xylem conduits.}

It has been suggested that the high hydraulic resistance exerted by oblique scalariform perforation plates may not be disadvantageous in environments with low transpiration rates such as tropical mountains and cool alpine regions (Baas, 1976; Carlquist, 2001; Jansen et al., 
2004; Lens et al., 2016). Likewise, vesselless angiosperms might be limited to wet forest habitats where their tracheid-based wood does not impose important hydraulic constraints, and may also be favored in freezing-prone environments (Feild et al., 2000; Feild et al., 2002). Given that the species included in this study are mainly distributed in rain forest ecosystems (Trueba et al., 2017), our results suggest that the species studied, which are characterized by low hydraulic safety and efficiency, have not experienced past climatic conditions that forced them to evolve an hydraulically efficient and embolism-resistant vascular apparatus. Species with both low efficiency and low safety are more common than expected (Gleason et al., 2016a), and the occurrence of species with this hydraulic profile in the New Caledonian archipelago might be explained by the presence of rain forest refugia during the climatic upheavals of the Pleistocene (Pouteau et al., 2015). Likewise, the persistence of mesic climatic conditions may have buffered New Caledonian species with vulnerable xylem conduits from the extreme climate shifts that strongly affected the vegetation of Australia and some nearby South Pacific Islands (Byrne et al., 2011).

Most of the species studied here are considered early diverging angiosperms because of their phylogenetic position, belonging to the ANA grade and the magnoliids, with the massive monocot-eudicots clade as subsequently diverging clade. New Caledonian early diverging angiosperms have a remarkable preference to rain forest habitats that exhibit high moisture levels and low diurnal and seasonal variations in temperature (Pouteau et al., 2015). Xylem embolism and its associated hydraulic failure is one of the most important mechanisms driving drought-induced mortality in moist tropical forests (Adams et al., 2017; McDowell et $a l ., 2018)$. It has been shown that species inhabiting similar environments can display different drought tolerances, ultimately showing different mortality rates after a drought event (Johnson et al., 2018). However, the lack of differentiation in hydraulic vulnerability between vessel-bearing angiosperms with scalariform perforation plates and co-occurring vesselless species suggests that, under the stable climatic conditions of the New Caledonian rainforest, species with different conduit types show a convergence of wood physiological features (Brodribb \& Feild, 2000). Given ongoing and projected increases in temperature averages in New Caledonia (Cavarero et al., 2012), our results suggest that drought will equally impact species with xylem conduits displaying very different morphologies. Extreme climate events in the rain forests of New Caledonia may therefore represent a major threat to the unique and charismatic flora of the archipelago. 


\section{Acknowledgements}

We thank Jeremy Girardi for assistance during fieldwork and light microscope image processing. We thank Vanessa Hequet for fieldwork assistance. We thank Fabian Carriconde, Valérie Medevielle and Léocadie Jamet for providing laboratory equipment. We thank Rob Langelaan for assistance in the preparation of samples and TEM imaging. We thank Felipe Zapata and Leila Fletcher for providing help in the implementation of PIC analysis. We thank Tim Brodribb, Taylor Feild and Adam Roddy for their insightful comments on the manuscript. S. Trueba was supported by CONACYT (grant no. 217745) and by the UCMEXUS postdoctoral program. This work was also supported by the 'Investments for the Future' (ANR-10-EQPX-16, XYLOFOREST) program and the Cluster of Excellence COTE (ANR-10-LABX-45, within the DEFI project) of the French National Agency for Research. 


\section{References}

Adams, H. D., M. J. Zeppel, W. R. Anderegg, H. Hartmann, S. M. Landhäusser, D. T. Tissue, T. E. Huxman, P. J. Hudson, T. E. Franz, et al. 2017. A multi-species synthesis of physiological mechanisms in drought-induced tree mortality. Nature Ecology \& Evolution 1: 1285.

Baas, P. 1976. Some functional and adaptive aspects of vessel member morphology. In: Baas, P, Bolton, A, J, Catling, D, M. eds. Wood structure in biological and technological research. Leiden University Press: 157-181.

Badel, E., F. Ewers, H. Cochard and F. W. Telewski. 2015. Acclimation of mechanical and hydraulic functions in trees: Impact of the thigmomorphogenetic process. Frontiers in plant science 6.

Bailey, I. W. and W. W. Tupper. 1918. Size variation in tracheary cells: I. A comparison between the secondary xylems of vascular cryptogams, gymnosperms and angiosperms. Proceedings of the American Academy of Arts and Sciences 54: 149-204.

Bailey, I. W. 1944. The Development of Vessels in Angiosperms and its Significance in Morphological Research. American Journal of Botany 31: 421-428.

Bennett, A. C., N. G. Mcdowell, C. D. Allen and K. J. Anderson-Teixeira. 2015. Larger trees suffer most during drought in forests worldwide. Nature Plants 1: 15139.

Blackman, C. J., T. J. Brodribb and G. J. Jordan. 2010. Leaf hydraulic vulnerability is related to conduit dimensions and drought resistance across a diverse range of woody angiosperms. New Phytologist 188: 1113-1123.

Bouche, P. S., M. Larter, J.-C. Domec, R. Burlett, P. Gasson, S. Jansen and S. Delzon. 2014. A broad survey of hydraulic and mechanical safety in the xylem of conifers. Journal of Experimental Botany 65: 4419-4431.

Brodersen, C., S. Jansen, B. Choat, C. Rico and J. Pittermann. 2014. Cavitation Resistance in Seedless Vascular Plants: The Structure and Function of Interconduit Pit Membranes. Plant Physiology 165: 895-904.

Brodribb, T. J. and T. S. Feild. 2000. Stem hydraulic supply is linked to leaf photosynthetic capacity: evidence from New Caledonian and Tasmanian rainforests. Plant, Cell \& Environment 23: 1381-1388.

Brodribb, T. J. and T. S. Feild. 2010. Leaf hydraulic evolution led a surge in leaf photosynthetic capacity during early angiosperm diversification. Ecology Letters 13: 175183.

Byrne, M., D. A. Steane, L. Joseph, D. K. Yeates, G. J. Jordan, D. Crayn, K. Aplin, D. J. Cantrill, L. G. Cook, et al. 2011. Decline of a biome: evolution, contraction, fragmentation, extinction and invasion of the Australian mesic zone biota. Journal of Biogeography 38: 1635-1656. 
Carlquist, S. 1992. Pit Membrane Remnants in Perforation Plates of Primitive Dicotyledons and Their Significance. American Journal of Botany 79: 660-672.

Carlquist, S. 2001. Comparative wood anatomy. Springer. Berlin.

Carlquist, S. and E. L. Schneider. 2002a. The tracheid-vessel element transition in angiosperms involves multiple independent features: cladistic consequences. American Journal of Botany 89: 185-195.

Carlquist, S. and E. L. Schneider. 2002b. Vessels of Illicium (Illiciaceae): Range of Pit Membrane Remnant Presence in Perforations and Other Vessel Details. International Journal of Plant Sciences 163: 755-763.

Carlquist, S. and E. K. Schneider. 2004. Perforation Plate Pit Membrane Remnants and Other Vessel Details of Clethraceae: Primitive Features in Wood of Ericales. International Journal of Plant Sciences 165: 369-375.

Carlquist, S. 2012. How wood evolves: a new synthesis. Botany 90: 901-940.

Cavarero, V., A. Peltier, X. Aubail, A. Leroy, B. Dubuisson, S. Jourdain, A. Ganachaud, A.-L. Gibelin, J. Lefèvre, et al. 2012. Les évolutions passées et futures du climat de la Nouvelle-Calédonie. La Météorologie 77: 13-21.

Choat, B., A. R. Cobb and S. Jansen. 2008. Structure and function of bordered pits: new discoveries and impacts on whole-plant hydraulic function. New Phytologist 177: 608-626.

Choat, B., S. Jansen, T. J. Brodribb, H. Cochard, S. Delzon, R. Bhaskar, S. J. Bucci, T. S. Feild, S. M. Gleason, et al. 2012. Global convergence in the vulnerability of forests to drought. Nature 491: 752-755.

Christman, M. A. and J. S. Sperry. 2010. Single-vessel flow measurements indicate scalariform perforation plates confer higher flow resistance than previously estimated. Plant, Cell \& Environment 33: 431-443.

Cochard, H., G. Damour, C. Bodet, I. Tharwat, M. Poirier and T. Améglio. 2005. Evaluation of a new centrifuge technique for rapid generation of xylem vulnerability curves. Physiologia Plantarum 124: 410-418.

Delzon, S., C. Douthe, A. Sala and H. Cochard. 2010. Mechanism of water-stress induced cavitation in conifers: bordered pit structure and function support the hypothesis of seal capillary-seeding. Plant, Cell \& Environment 33: 2101-2111.

Dickison, W. C. and P. Baas. 1977. The morphology and relationships of Paracryphia (Paracryphiaceae). Blumea-Biodiversity, Evolution and Biogeography of Plants 23: 417438.

Domec, J.-C. and B. L. Gartner. 2001. Cavitation and water storage capacity in bole xylem segments of mature and young Douglas-fir trees. Trees 15: 204-214.

Dória, L. C., D. S. Podadera, M. Arco, T. Chauvin, E. Smets, S. Delzon and F. Lens. 2018. Insular woody daisies (Argyranthemum, Asteraceae) are more resistant to drought- 
induced hydraulic failure than their herbaceous relatives. Functional Ecology 32: 14671478.

Dória, L. C., C. Meijs, D. S. Podadera, M. Del Arco, E. Smets, S. Delzon and F. Lens. 2019. Embolism resistance in stems of herbaceous Brassicaceae and Asteraceae is linked to differences in woodiness and precipitation. Annals of Botany.

Duursma, R. and B. Choat. 2017. fitplc - an R package to fit hydraulic vulnerability curves. 20174.

Feild, T. S., M. A. Zwieniecki and N. M. Holbrook. 2000. Winteraceae Evolution: An Ecophysiological Perspective. Annals of the Missouri Botanical Garden 87: 323-334.

Feild, T. S., T. Brodribb and N. M. Holbrook. 2002. Hardly a relict: freezing and the evolution of vesselless wood in Winteraceae. Evolution 56: 464-478.

Feild, T. S., N. C. Arens and T. E. Dawson. 2003. The Ancestral Ecology of Angiosperms: Emerging Perspectives from Extant Basal Lineages. International Journal of Plant Sciences 164: S129-S142.

Feild, T. S., N. C. Arens, J. A. Doyle, T. E. Dawson and M. J. Donoghue. 2004. Dark and disturbed: a new image of early angiosperm ecology. Paleobiology 30: 82-107.

Feild, T. S. and N. C. Arens. 2007. The ecophysiology of early angiosperms. Plant, Cell \& Environment 30: 291-309.

Feild, T. S., P. J. Hudson, L. Balun, D. S. Chatelet, A. A. Patino, C. A. Sharma and K. Mclaren. 2011. The Ecophysiology of Xylem Hydraulic Constraints by "Basal" Vessels in Canella winterana (Canellaceae). International Journal of Plant Sciences 172: 879-888.

Feild, T. S. and J. P. Wilson. 2012. Evolutionary voyage of angiosperm vessel structurefunction and its significance for early angiosperm success. International Journal of Plant Sciences 173: 596-609.

Feild, T. S., D. S. Chatelet, L. Balun, E. E. Schilling and R. Evans. 2012. The evolution of angiosperm lianescence without vessels - climbing mode and wood structure-function in Tasmannia cordata (Winteraceae). New Phytologist 193: 229-240.

Feild, T. S. and T. J. Brodribb. 2013. Hydraulic tuning of vein cell microstructure in the evolution of angiosperm venation networks. New Phytologist 199: 720-726.

Felsenstein, J. 1985. Phylogenies and the Comparative Method. The American Naturalist 125: $1-15$

Fichot, R., T. S. Barigah, S. Chamaillard, D. Le Thiec, F. Laurans, H. Cochard and F. Brignolas. 2010. Common trade-offs between xylem resistance to cavitation and other physiological traits do not hold among unrelated Populus deltoides $\times$ Populus nigra hybrids. Plant, Cell \& Environment 33: 1553-1568.

Gleason, S. M., M. Westoby, S. Jansen, B. Choat, U. G. Hacke, R. B. Pratt, R. Bhaskar, T. J. Brodribb, S. J. Bucci, et al. 2016a. Weak tradeoff between xylem safety and 
xylem-specific hydraulic efficiency across the world's woody plant species. New Phytologist 209: 123-136.

Gleason, S. M., M. Westoby, S. Jansen, B. Choat, T. J. Brodribb, H. Cochard, S. Delzon, U. G. Hacke, A. L. Jacobsen, et al. 2016b. On research priorities to advance understanding of the safety-efficiency tradeoff in xylem. New Phytologist 211: 1156-1158.

Hacke, U. G., J. S. Sperry, W. T. Pockman, S. D. Davis and K. A. Mcculloh. 2001. Trends in wood density and structure are linked to prevention of xylem implosion by negative pressure. Oecologia 126: 457-461.

Hacke, U. G., J. S. Sperry, J. K. Wheeler and L. Castro. 2006. Scaling of angiosperm xylem structure with safety and efficiency. Tree Physiology 26: 689-701.

Hacke, U. G., J. S. Sperry, T. S. Feild, Y. Sano, E. H. Sikkema and J. Pittermann. 2007. Water transport in vesselless angiosperms: conducting efficiency and cavitation safety. International Journal of Plant Sciences 168: 1113-1126.

Hacke, U. G., R. Spicer, S. G. Schreiber and L. Plavcová. 2017. An ecophysiological and developmental perspective on variation in vessel diameter. Plant, Cell \& Environment 40: 831-845.

Hudson, P. J., J. Razanatsoa and T. S. Feild. 2010. Early vessel evolution and the diverisification of wood function: Insights from Malagasy Canellales. American Journal of Botany 97: 80-93.

Jacobsen, A. L., F. W. Ewers, R. B. Pratt, W. A. Paddock and S. D. Davis. 2005. Do Xylem Fibers Affect Vessel Cavitation Resistance? Plant Physiology 139: 546-556.

Jansen, S., P. Baas, P. Gasson, F. Lens and E. Smets. 2004. Variation in xylem structure from tropics to tundra: Evidence from vestured pits. Proceedings of the National Academy of Sciences of the United States of America 101: 8833-8837.

Jansen, S., B. Choat and A. Pletsers. 2009. Morphological variation of intervessel pit membranes and implications to xylem function in angiosperms. American Journal of Botany 96: 409-419.

Johnson, D. M., J.-C. Domec, Z. C. Berry, A. M. Schwantes, D. R. Woodruff, K. A. Mcculloh, H. W. Polley, R. Wortemann, J. J. Swenson, et al. 2018. Co-occurring woody species have diverse hydraulic strategies and mortality rates during an extreme drought. Plant, Cell \& Environment: n/a-n/a.

Jordan, G. J., T. J. Brodribb, C. J. Blackman and P. H. Weston. 2013. Climate drives vein anatomy in Proteaceae. American Journal of Botany 100: 1483-1493.

Karnovsky, M., J 1965. A formaldehyde glutaraldehyde fixative of high osmolality for use in electron microscopy. Journal of Cell Biology 27: 137-138.

Lens, F., J. S. Sperry, M. A. Christman, B. Choat, D. Rabaey and S. Jansen. 2011. Testing hypotheses that link wood anatomy to cavitation resistance and hydraulic conductivity in the genus Acer. New Phytologist 190: 709-723. 
Lens, F., A. Tixier, H. Cochard, J. S. Sperry, S. Jansen and S. Herbette. 2013. Embolism resistance as a key mechanism to understand adaptive plant strategies. Current Opinion in Plant Biology 16: 287-292.

Lens, F., R. A. Vos, G. Charrier, T. Van Der Niet, V. Merckx, P. Baas, J. Aguirre Gutierrez, B. Jacobs, L. Chacon Dória, et al. 2016. Scalariform-to-simple transition in vessel perforation plates triggered by differences in climate during the evolution of Adoxaceae. Annals of Botany 118: 1043-1056.

Li, S., F. Lens, S. Espino, Z. Karimi, M. Klepsch, H. J. Schenk, M. Schmitt, B. Schuldt and S. Jansen. 2016. Intervessel pit membrane thickness as a key determinant of embolism resistance in angiosperm xylem. Iawa Journal 37: 152-171.

Loepfe, L., J. Martinez-Vilalta, J. Piñol and M. Mencuccini. 2007. The relevance of xylem network structure for plant hydraulic efficiency and safety. Journal of Theoretical Biology 247: 788-803.

Magallón, S., S. Gómez-Acevedo, L. L. Sánchez-Reyes and T. Hernández-Hernández. 2015. A metacalibrated time-tree documents the early rise of flowering plant phylogenetic diversity. New Phytologist 207: 437-453.

Martin-Stpaul, N., S. Delzon and H. Cochard. 2017. Plant resistance to drought depends on timely stomatal closure. Ecology Letters 20: 1437-1447.

Mcdowell, N., D. Allen Craig, K. Anderson-Teixeira, P. Brando, R. Brienen, J. Chambers, B. Christoffersen, S. Davies, C. Doughty, et al. 2018. Drivers and mechanisms of tree mortality in moist tropical forests. New Phytologist 219: 851-869.

Ogle, K., J. J. Barber, C. Willson and B. Thompson. 2009. Hierarchical statistical modeling of xylem vulnerability to cavitation. New Phytologist 182: 541-554.

Olson, M. E. 2014. Xylem hydraulic evolution, I. W. Bailey, and Nardini \& Jansen (2013): pattern and process. New Phytologist 203: 7-11.

Olson, M. E., D. Soriano, J. A. Rosell, T. Anfodillo, M. J. Donoghue, E. J. Edwards, C. León-Gómez, T. Dawson, J. J. Camarero Martínez, et al. 2018. Plant height and hydraulic vulnerability to drought and cold. Proceedings of the National Academy of Sciences.

Paradis, E., J. Claude and K. Strimmer. 2004. APE: Analyses of Phylogenetics and Evolution in R language. Bioinformatics 20: 289-290.

Pittermann, J. and J. Sperry. 2003. Tracheid diameter is the key trait determining the extent of freezing-induced embolism in conifers. Tree Physiology 23: 907-914.

Pittermann, J., B. Choat, S. Jansen, S. A. Stuart, L. Lynn and T. E. Dawson. 2010. The Relationships between Xylem Safety and Hydraulic Efficiency in the Cupressaceae: The Evolution of Pit Membrane Form and Function. Plant Physiology 153: 1919-1931.

Poorter, L., I. Mcdonald, A. Alarcón, E. Fichtler, J.-C. Licona, M. Peña-Claros, F. Sterck, Z. Villegas and U. Sass-Klaassen. 2010. The importance of wood traits and 
hydraulic conductance for the performance and life history strategies of 42 rainforest tree species. New Phytologist 185: 481-492.

Pouteau, R., S. Trueba, T. S. Feild and S. Isnard. 2015. New Caledonia: a Pleistocene refugium for rain forest lineages of relict angiosperms. Journal of Biogeography 42: 20622077.

R Core Team. 2017. R: A language and environment for statistical computing. Vienna, Austria: R Foundation for Statistical Computing

Rosner, S., N. Gierlinger, M. Klepsch, B. Karlsson, R. Evans, S.-O. Lundqvist, J. Světlík, I. Børja, L. Dalsgaard, et al. 2018. Hydraulic and mechanical dysfunction of Norway spruce sapwood due to extreme summer drought in Scandinavia. Forest Ecology and Management 409: 527-540.

Sano, Y., H. Morris, H. Shimada, L. P. Ronse De Craene and S. Jansen. 2011. Anatomical features associated with water transport in imperforate tracheary elements of vessel-bearing angiosperms. Annals of Botany 107: 953-964.

Schenk, H. J., K. Steppe and S. Jansen. 2015. Nanobubbles: a new paradigm for air-seeding in xylem. Trends in plant science 20: 199-205.

Schenk, H. J., S. Espino, D. M. Romo, N. Nima, A. Y. T. Do, J. M. Michaud, B. Papahadjopoulos-Sternberg, J. Yang, Y. Y. Zuo, et al. 2016. Xylem surfactants introduce a new element to the cohesion-tension theory. Plant Physiology.

Scholz, A., M. Klepsch, Z. Karimi and S. Jansen. 2013. How to quantify conduits in wood? Frontiers in plant science 4 .

Smith, S. A. and J. W. Brown. 2018. Constructing a broadly inclusive seed plant phylogeny. American Journal of Botany 105: 302-314.

Sperry, J. S. 2003. Evolution of Water Transport and Xylem Structure. International Journal of Plant Sciences 164: S115-S127.

Sperry, J. S., U. G. Hacke and J. Pittermann. 2006. Size and function in conifer tracheids and angiosperm vessels. American Journal of Botany 93: 1490-1500.

Sperry, J. S., U. G. Hacke, T. S. Feild, Y. Sano and E. H. Sikkema. 2007. Hydraulic consequences of vessel evolution in angiosperms. International Journal of Plant Sciences 168: $1127-1139$.

Spicer, R. and A. Groover. 2010. Evolution of development of vascular cambia and secondary growth. New Phytologist 186: 577-592.

Tixier, A., S. Herbette, S. Jansen, M. Capron, P. Tordjeman, H. Cochard and E. Badel. 2014. Modelling the mechanical behaviour of pit membranes in bordered pits with respect to cavitation resistance in angiosperms. Annals of Botany. 
Trueba, S., S. Isnard, D. Barthélémy and M. E. Olson. 2016. Trait coordination, mechanical behaviour and growth form plasticity of Amborella trichopoda under variation in canopy openness. AoB Plants 8.

Trueba, S., R. Pouteau, F. Lens, T. S. Feild, S. Isnard, M. E. Olson and S. Delzon. 2017. Vulnerability to xylem embolism as a major correlate of the environmental distribution of rain forest species on a tropical island. Plant, Cell \& Environment 40: 277-289.

Tyree, M. T. and J. S. Sperry. 1989. Vulnerability of Xylem to Cavitation and Embolism. Annual Review of Plant Physiology and Plant Molecular Biology 40: 19-36.

Tyree, M. T. and M. H. Zimmermann. 2002. Xylem structure and the ascent of sap. Springer.

Warton, D. I., R. A. Duursma, D. S. Falster and S. Taskinen. 2012. smatr 3- an R package for estimation and inference about allometric lines. Methods in Ecology and Evolution 3: 257-259.

Zanne, A. E., M. Westoby, D. S. Falster, D. D. Ackerly, S. R. Loarie, S. E. J. Arnold and D. A. Coomes. 2010. Angiosperm wood structure: Global patterns in vessel anatomy and their relation to wood density and potential conductivity. American Journal of Botany 97: 207-215.

Zhang, Y., M. Klepsch and S. Jansen. 2017. Bordered pits in xylem of vesselless angiosperms and their possible misinterpretation as perforation plates. Plant, Cell \& Environment 40: 2133-2146. 


\section{TABLES}

Table 1. Abbreviations and definitions of xylem anatomical and hydraulic variables measured, with reference to their units

\begin{tabular}{lll}
\hline Abbreviation & Definition & Units employed \\
\hline CD & Xylem conduit density per unit sapwood area & $\mathrm{N} \mathrm{mm}^{-2}$ \\
$D_{\mathrm{H}}$ & Hydraulically weighted mean conduit diameter & $\mu \mathrm{m}$ \\
$D_{\mathrm{m}}$ & Horizontal pit membrane diameter & $\mu \mathrm{m}$ \\
$D_{\mathrm{pa}}$ & Horizontal pit aperture diameter & $\mu \mathrm{m}$ \\
$K_{\mathrm{s}}$ & Measured stem hydraulic conductivity & $\mathrm{kg} \mathrm{m}^{-1} \mathrm{MPa}^{-1} \mathrm{~s}^{-1}$ \\
$K_{\mathrm{th}}$ & Theoretical xylem specific hydraulic conductivity & $\mathrm{kg} \mathrm{m}^{-1} \mathrm{MPa}^{-1} \mathrm{~s}^{-1}$ \\
$L_{\mathrm{p}}$ & Depth of pit chamber from relaxed pit membrane to inner & $\mathrm{nm}$ \\
$P_{12}$ & edge of pit aperture & \\
& Water potential at 12\% loss of stem hydraulic & $\mathrm{MPa}$ \\
$P_{50}$ & conductivity & \\
$S_{50}$ & Water potential at $50 \%$ loss of stem hydraulic & $\mathrm{MPa}$ \\
$T_{\mathrm{w}}$ & conductivity & $\% \mathrm{MPa}^{-1}$ \\
$T_{\mathrm{m}}$ & Slope of the vulnerability curve at $P_{50}$ & $\mu \mathrm{m}$ \\
$(t / b)^{2}$ & Double thickness of two adjacent conduits & $\mathrm{nm}$ \\
\hline & Thickness of the interconduit pit membrane & $\mathrm{no} \mathrm{unit}$ \\
\hline & Xylem conduit wall reinforcement &
\end{tabular}


Table 2. Origin of species studied in New Caledonia, along with the phylogenetic placement at the family level, and the anatomical and hydraulic observations

\begin{tabular}{|c|c|c|c|c|c|c|c|c|c|c|c|c|c|c|}
\hline Species & Family & Locality & $\begin{array}{c}\text { Condu } \\
\text { it }\end{array}$ & $K_{\mathrm{s}}$ & $K_{\text {th }}$ & $P_{12}$ & $P_{50}$ & $S_{50}$ & CD & $D_{\mathbf{H}}$ & $L_{\mathbf{p}}$ & $T_{\mathrm{w}}$ & $T_{\mathrm{m}}$ & $(t / b)^{2}$ \\
\hline $\begin{array}{l}\text { Amborella } \\
\text { trichopoda }\end{array}$ & Amborellaceae & $\begin{array}{c}\text { Mt. } \\
\text { Aoupinié }\end{array}$ & $\mathrm{T}$ & 0.437 & 7.74 & 2.17 & 2.68 & $\begin{array}{c}10 \\
5\end{array}$ & $\begin{array}{l}1229 \\
\pm 49\end{array}$ & $\begin{array}{r}22.53 \\
\pm 0.79\end{array}$ & $\begin{array}{c}919 \pm \\
23\end{array}$ & $\begin{array}{c}5.39 \pm \\
0.16\end{array}$ & $\begin{array}{l}273 \\
\pm 13\end{array}$ & $\begin{array}{l}0.09 \pm \\
0.010\end{array}$ \\
\hline $\begin{array}{l}\text { Ascarina } \\
\text { rubricaulis }\end{array}$ & Chloranthaceae & Mt. Dzumac & $\mathrm{V}, \mathrm{Sc}$ & 0.890 & 24.12 & 1.59 & 2.28 & 71 & $\begin{array}{c}237 \pm \\
21\end{array}$ & $\begin{array}{l}45.17 \\
\pm 1.49\end{array}$ & $\begin{array}{l}1156 \\
\pm 41\end{array}$ & $\begin{array}{c}6.88 \pm \\
0.21\end{array}$ & $\begin{array}{l}260 \\
\pm 13\end{array}$ & $\begin{array}{l}0.04 \pm \\
0.005\end{array}$ \\
\hline $\begin{array}{c}\text { Hedycarya } \\
\text { cupulata }\end{array}$ & Monimiaceae & $\begin{array}{c}\text { Mt. } \\
\text { Aoupinié }\end{array}$ & $\mathrm{V}, \mathrm{Sc}$ & 0.104 & 6.83 & 1.39 & 3.09 & 24 & $\begin{array}{c}173 \pm \\
15\end{array}$ & $\begin{array}{l}35.64 \\
\pm 1.37\end{array}$ & $\begin{array}{c}988 \\
37\end{array}$ & $\begin{array}{c}5.41 \pm \\
0.26\end{array}$ & $\begin{array}{l}348 \\
\pm 7\end{array}$ & $\begin{array}{l}0.05 \pm \\
0.009\end{array}$ \\
\hline $\begin{array}{c}\text { Hedycarya } \\
\text { parvifolia }\end{array}$ & Monimiaceae & $\begin{array}{c}\text { Mt. } \\
\text { Aoupinié }\end{array}$ & $\mathrm{V}, \mathrm{Sc}$ & 0.233 & 12.36 & & 3.23 & 60 & $\begin{array}{c}148 \pm \\
18\end{array}$ & $\begin{array}{r}39.03 \\
\pm 1.48\end{array}$ & $\begin{array}{l}1246 \\
\pm 90\end{array}$ & $\begin{array}{c}9.07 \pm \\
0.35\end{array}$ & $\begin{array}{l}388 \\
\pm 26\end{array}$ & $\begin{array}{l}0.04 \pm \\
0.004\end{array}$ \\
\hline $\begin{array}{l}\text { Kibaropsis } \\
\text { caledonica }\end{array}$ & Monimiaceae & $\begin{array}{c}\text { Mt. } \\
\text { Aoupinié }\end{array}$ & $\mathrm{V}, \mathrm{Sc}$ & 0.257 & & & & 50 & $\begin{array}{c}236 \pm \\
11\end{array}$ & $\begin{array}{r}38.04 \\
\pm 1.02\end{array}$ & $\begin{array}{l}1005 \\
\pm 53\end{array}$ & $\begin{array}{c}7.43 \pm \\
0.15\end{array}$ & $\begin{array}{l}268 \\
\pm 15\end{array}$ & $\begin{array}{l}0.05 \pm \\
0.004\end{array}$ \\
\hline $\begin{array}{c}\text { Nemuaron } \\
\text { viellardii }\end{array}$ & $\begin{array}{l}\text { Atherospermatace } \\
\text { ae }\end{array}$ & Mt. Dzumac & $\mathrm{V}, \mathrm{Sc}$ & 0.791 & 23.03 & 1.43 & 2.30 & 54 & $\begin{array}{c}307 \pm \\
19\end{array}$ & $\begin{array}{l}41.85 \\
\pm 1.42\end{array}$ & $\begin{array}{c}915 \\
58\end{array}$ & $\begin{array}{c}6.96 \pm \\
0.41\end{array}$ & $\begin{array}{l}202 \\
\pm 8\end{array}$ & $\begin{array}{l}0.06 \pm \\
0.012\end{array}$ \\
\hline $\begin{array}{c}\text { Paracryphi } \\
\text { a alticola }\end{array}$ & Paracryphiaceae & $\begin{array}{c}\text { Mt. } \\
\text { Humboldt }\end{array}$ & $\mathrm{V}, \mathrm{Sc}$ & 0.161 & 2.73 & $0 . \overline{77}$ & 2.02 & 30 & $\begin{array}{c}136 \pm \\
10\end{array}$ & $\begin{array}{l}30.09 \\
\pm 0.71\end{array}$ & $\begin{array}{c}694 \pm \\
42\end{array}$ & $\begin{array}{c}5.69 \pm \\
0.20\end{array}$ & $\begin{array}{r}169 \\
\pm 8\end{array}$ & $\begin{array}{l}0.04 \pm \\
0.003\end{array}$ \\
\hline $\begin{array}{l}\text { Quintinia } \\
\text { major }\end{array}$ & Paracryphiaceae & $\begin{array}{c}\text { Mt. } \\
\text { Humboldt }\end{array}$ & & 10 & 6.91 & 1.08 & 2.47 & 29 & $\begin{array}{c}180 \pm \\
9\end{array}$ & $\begin{array}{l}35.39 \\
\pm 0.55\end{array}$ & $\begin{array}{c}855 \\
73\end{array}$ & $\begin{array}{c}7.79 \pm \\
0.83\end{array}$ & $\begin{array}{r}229 \\
\pm 9\end{array}$ & $\begin{array}{l}0.08 \pm \\
0.025\end{array}$ \\
\hline $\begin{array}{l}\text { Zygogynum } \\
\text { acsmithii }\end{array}$ & Winteraceae & $\begin{array}{l}\text { Wadjana, } \\
\text { Yaté }\end{array}$ & & & 11.53 & $2 . \overline{39}$ & $2 . \overline{73}$ & $\begin{array}{c}16 \\
2\end{array}$ & $\begin{array}{l}1211 \\
\pm 48\end{array}$ & $\begin{array}{l}24.98 \\
\pm 0.82\end{array}$ & $\begin{array}{l}1031 \\
\pm 20\end{array}$ & $\begin{array}{c}9.78 \pm \\
0.32\end{array}$ & $\begin{array}{l}253 \\
\pm 6\end{array}$ & $\begin{array}{l}0.23 \pm \\
0.021\end{array}$ \\
\hline $\begin{array}{l}\text { Zygogynum } \\
\text { crassifolium }\end{array}$ & Winteraceae & $\begin{array}{c}\text { Pic du Pin, } \\
\text { Yaté }\end{array}$ & $T$ & 0.615 & 3.87 & 3.50 & 4.11 & 89 & $\begin{array}{l}1037 \\
\pm 24\end{array}$ & $\begin{array}{l}19.77 \\
\pm 0.50\end{array}$ & $\begin{array}{l}1259 \\
\pm 77\end{array}$ & $\begin{array}{r}13.25 \\
\pm 0.31\end{array}$ & $\begin{array}{l}274 \\
\pm 16\end{array}$ & $\begin{array}{l}0.55 \pm \\
0.040\end{array}$ \\
\hline $\begin{array}{l}\text { Zygogynum } \\
\text { stipitatum }\end{array}$ & Winteraceae & $\begin{array}{c}\text { Wadjana, } \\
\text { Yaté }\end{array}$ & $\mathrm{T}$ & 0.325 & 5.53 & 1.80 & 2.44 & 78 & $\begin{array}{l}1121 \\
\pm 59\end{array}$ & $\begin{array}{l}21.19 \\
\pm 0.74\end{array}$ & $\underset{36}{921} \pm$ & $\begin{array}{c}9.79 \pm \\
0.26\end{array}$ & $\begin{array}{l}215 \\
\pm 6\end{array}$ & $\begin{array}{l}0.36 \pm \\
0.042\end{array}$ \\
\hline $\begin{array}{c}\text { Zygogynum } \\
\text { thieghemii }\end{array}$ & Winteraceae & $\begin{array}{l}\text { Mt. } \\
\text { Humboldt }\end{array}$ & $\mathrm{T}$ & 0.658 & 7.62 & 1.62 & 2.29 & 75 & $\begin{array}{c}862 \pm \\
36\end{array}$ & $\begin{array}{r}24.52 \\
\pm 0.79\end{array}$ & $\begin{array}{r}1289 \\
\pm 91 \\
\end{array}$ & $\begin{array}{r}13.59 \\
\pm 0.37 \\
\end{array}$ & $\begin{array}{r}276 \\
\pm 17 \\
\end{array}$ & $\begin{array}{r}0.46 \pm \\
0.039 \\
\end{array}$ \\
\hline
\end{tabular}

Values are mean \pm SE. The main conductive elements in xylem are indicated as "T" = tracheids in vesselless species; "V Sc" = vessels with scalariform perforation plates in vessel-bearing species. See Table 1 for a description of abbreviations and units of measurements. 
Table 3. Differences in anatomical and hydraulic trait values between vesselless angiosperms $(n=5)$ and vessel-bearing species with scalariform perforation plates $(n=7)$.

\begin{tabular}{cccccc}
\hline Trait & $\begin{array}{c}\text { Mean } \\
\text { vesselless }\end{array}$ & $\begin{array}{c}\text { Mean } \\
\text { vessel-bearing }\end{array}$ & $\boldsymbol{t}$ & $\mathbf{d f}$ & $\boldsymbol{P}$ \\
\hline $\mathrm{CD}$ & 1092 & 202 & 12.57 & 4.94 & $<\mathbf{0 . 0 0 1}$ \\
$D_{\mathrm{H}}$ & 22.60 & 38.45 & -7.17 & 8.55 & $<\mathbf{0 . 0 0 1}$ \\
$D_{\mathrm{m}}$ & 8.81 & 9.07 & -0.25 & 9.51 & 0.8061 \\
$D_{\mathrm{pa}}$ & 1.74 & 3.01 & -1.93 & 6.54 & 0.0973 \\
$K_{\mathrm{s}}$ & 0.52 & 0.37 & 1.10 & 8.52 & 0.2998 \\
$K_{\mathrm{th}}$ & 7.26 & 12.58 & -1.58 & 7.89 & 0.1527 \\
$L_{\mathrm{p}}$ & 1084 & 980 & 0.98 & 8.92 & 0.3545 \\
$P_{12}$ & -2.30 & -1.46 & 2.21 & 6.60 & 0.0652 \\
$P_{50}$ & -2.85 & -2.55 & 0.81 & 6.10 & 0.4478 \\
$S_{50}$ & 102 & 45 & 3.27 & 5.47 & $<\mathbf{0 . 0 5}$ \\
$T_{\mathrm{w}}$ & 10.36 & 7.03 & 2.13 & 4.81 & 0.0880 \\
$T_{\mathrm{m}}$ & 258 & 266 & -0.26 & 7.74 & 0.8041 \\
$(t / b)^{2}$ & 0.338 & 0.049 & 3.52 & 4.03 & $<\mathbf{0 . 0 5}$ \\
\hline
\end{tabular}

Mean trait values for each vascular type, list of statistics $(t)$, degrees of freedom (df), and significance values $(P)$ of independent $t$-test are provided. Graphical comparisons of focal traits are provided in Figure 2. See Table 1 for a list of abbreviations and units. 
Table 4. Pearson and phylogenetic independent contrast correlations between hydraulic and anatomic traits.

\begin{tabular}{|c|c|c|c|c|c|c|c|c|c|c|c|c|c|}
\hline & $P_{12}$ & $P_{50}$ & $S_{50}$ & $\boldsymbol{K}_{\mathrm{s}}$ & $K_{\text {th }}$ & $(t / b)^{2}$ & CD & $D_{\mathrm{H}}$ & $T_{\mathrm{w}}$ & $T_{\mathrm{m}}$ & $L_{\mathrm{p}}$ & $D_{\text {pa }}$ & $D_{\mathrm{m}}$ \\
\hline$P_{12}$ & & $0.84 * * *$ & $0.64 *$ & 0.32 & -0.11 & $0.60 *$ & $0.61 *$ & -0.42 & 0.58* & 0.41 & $0.65 *$ & -0.25 & 0.30 \\
\hline$P_{50}$ & $0.89 * *$ & & 0.20 & -0.05 & -0.28 & 0.43 & 0.25 & -0.25 & 0.40 & $0.58 *$ & 0.54 & -0.26 & 0.24 \\
\hline$S_{50}$ & 0.23 & 0.09 & & 0.48 & 0.07 & 0.42 & $0.83 * * *$ & -0.50 & 0.39 & 0 & 0.31 & -0.22 & 0.03 \\
\hline$K_{\mathrm{s}}$ & 0.19 & 0.11 & 0 & & $0.65 *$ & 0.31 & 0.32 & 0.23 & 0.34 & -0.18 & 0.46 & 0.44 & 0.19 \\
\hline$K_{\text {th }}$ & 0.12 & 0.53 & $0.78 *$ & 0.29 & & -0.42 & -0.30 & $\mathbf{0 . 7 2 * *}$ & -0.23 & 0.01 & 0.19 & $0.67 *$ & 0.09 \\
\hline$(t / b)^{2}$ & 0.34 & 0.50 & 0.74 & 0.44 & 0.71 & & $0.69 *$ & $-0.76^{* *}$ & $0.9 * * *$ & -0.06 & 0.50 & -0.33 & 0.13 \\
\hline CD & 0.31 & 0.16 & 0.78* & 0.02 & 0.34 & 0.37 & & $-0.85 * * *$ & 0.48 & -0.11 & 0.20 & -0.44 & -0.14 \\
\hline$D_{\mathrm{H}}$ & 0.07 & 0.40 & 0.44 & 0.23 & $0.81 *$ & 0.51 & 0.19 & & -0.48 & 0.23 & 0 & $0.63 *$ & 0.16 \\
\hline$T_{\mathrm{w}}$ & 0.36 & 0.20 & 0.35 & $0.83 *$ & 0.05 & 0.70 & 0.41 & 0.22 & & 0.11 & $0.70 *$ & -0.22 & 0.23 \\
\hline$T_{\mathrm{m}}$ & 0.34 & 0.37 & 0.11 & 0.02 & 0.08 & 0.19 & 0.31 & 0.36 & 0.4 & & $0.65 *$ & 0.01 & 0.29 \\
\hline$L_{\mathrm{p}}$ & 0.39 & 0.28 & 0.34 & 0.67 & 0.06 & 0.63 & 0.47 & 0.31 & $0.94 * *$ & 0.67 & & 0.19 & 0.50 \\
\hline$D_{\mathrm{pa}}$ & 0.25 & 0.07 & $0.76^{*}$ & 0.13 & 0.39 & 0.49 & $0.86^{*}$ & 0.13 & 0.52 & 0.61 & 0.65 & & 0.39 \\
\hline$D_{\mathrm{m}}$ & 0.73 & 0.54 & 0.07 & 0.51 & 0.01 & 0.47 & 0.27 & 0.32 & $0.80 *$ & 0.51 & $0.81 *$ & 0.27 & \\
\hline
\end{tabular}

Correlations based on average values of vesselless and vessel-bearing angiosperm species. Pearson correlation coefficients (r) and phylogenetic independent contrast correlations (PICs) values are provided above and below the diagonal, respectively. PIC analyses were performed on a subset of nine species (see Materials and Methods). Significant correlations are shown in bold. See Table 1 in the main text for abbreviations and units. * $P \leq 0.05 ; * * P \leq 0.01 ; * * * P \leq 0.001$. 


\section{FIGURE LEGENDS}

Figure 1. Transverse microscopic wood sections of the vesselless Amborella trichopoda (a) and the vessel-bearing Ascarina rubricaulis (b) observed with light microscope. Black arrows indicate tracheids (a) or vessels (b). Compelling differences in xylem conduit diameter $\left(D_{\mathrm{h}}\right)$ and conduit density (CD) are observed. Both species present uniseriate and multiseriate rays (white arrows). $\mathrm{P}=$ pith; $\mathrm{X}=\mathrm{xylem}$. Scale bars $=500 \mu \mathrm{m}$, and $225 \mu \mathrm{m}$ for insets.

Figure 2. Comparison of hydraulic and anatomical trait values amongst vesselless (red boxes) and vessel-bearing species with scalariform perforation plates (blue boxes). Boxes and bars show the median, 0.25 and 0.75 percentiles and extreme values. $P$-values of comparisons between species with different xylem conduit types are included.

Figure 3. Relation between theoretical hydraulic conductivity based on anatomical measurements $\left(K_{\text {th }}\right)$ and measured stem specific hydraulic conductivity $\left(K_{\mathrm{s}}\right)$. Vessel-bearing species (blue points) and vesselless species (red points) are indicated. SMA regression is included. $* P \leq 0.05$.

Figure 4. Vulnerability curves fitted using a Weibull model showing the percentage loss of xylem hydraulic conductivity $(\%)$ as a function of declining water potential $(\mathrm{MPa})$ for each of the 12 species studied. The best fit line is provided and shaded polygons represent $95 \%$ confidence intervals (CI). Vertical blue lines indicate the xylem pressure inducing $50 \%$ loss of hydraulic conductivity $\left(\mathrm{P}_{50}\right)$ including $95 \% \mathrm{CI}$ (dashed lines). Vesselless species bearing only tracheids (T) and vessel-bearing species with scalariform perforation plates (V) are indicated.

Figure 5. Relation of pit ultrastructural traits with xylem embolism vulnerability. (A) Thickness of interconduit pit membrane $\left(T_{\mathrm{m}}\right)$ is significantly related to xylem embolism vulnerability $\left(P_{50}\right)$. (B) Lack of relationship between depth of pit chamber $\left(L_{\mathrm{p}}\right)$ and embolism vulnerability $\left(P_{50}\right)$. Vessel-bearing species with scalariform perforation plates (blue points) and vesselless species (red points) along with correlation values for each vascular type are indicated. $n s=$ non significant; $* P \leq 0.05 ; * * * P \leq 0.001$.

Figure 6. TEM images of interconduit lateral pits in vesselless (A, B) and vessel-bearing (C, D) angiosperms illustrating species that are vulnerable to embolism (left) and more embolism resistant species (right). (A) Zygogynum stipitatum. (B) Z. acsmithii. (C) Paracryphia alticola. (D) Hedycarya parvifolia. Arrows indicate pit membranes. Scale bars $=2 \mu \mathrm{m}$.

Figure 7. SEM images of vessel elements bearing scalariform perforation plates with different morphologies. $a$ and $b$; radial view of scalariform perforation plates (black arrows). $c$ and d; membrane remnants in pits of scalariform perforation plates (white arrows). (a, c) Hedycarya cupulata. (b, d) Paracryphia alticola. Scale bars $=150 \mu \mathrm{m}$ in a and b; $70 \mu \mathrm{m}$ in c; $30 \mu \mathrm{m}$ in $\mathrm{d}$. 

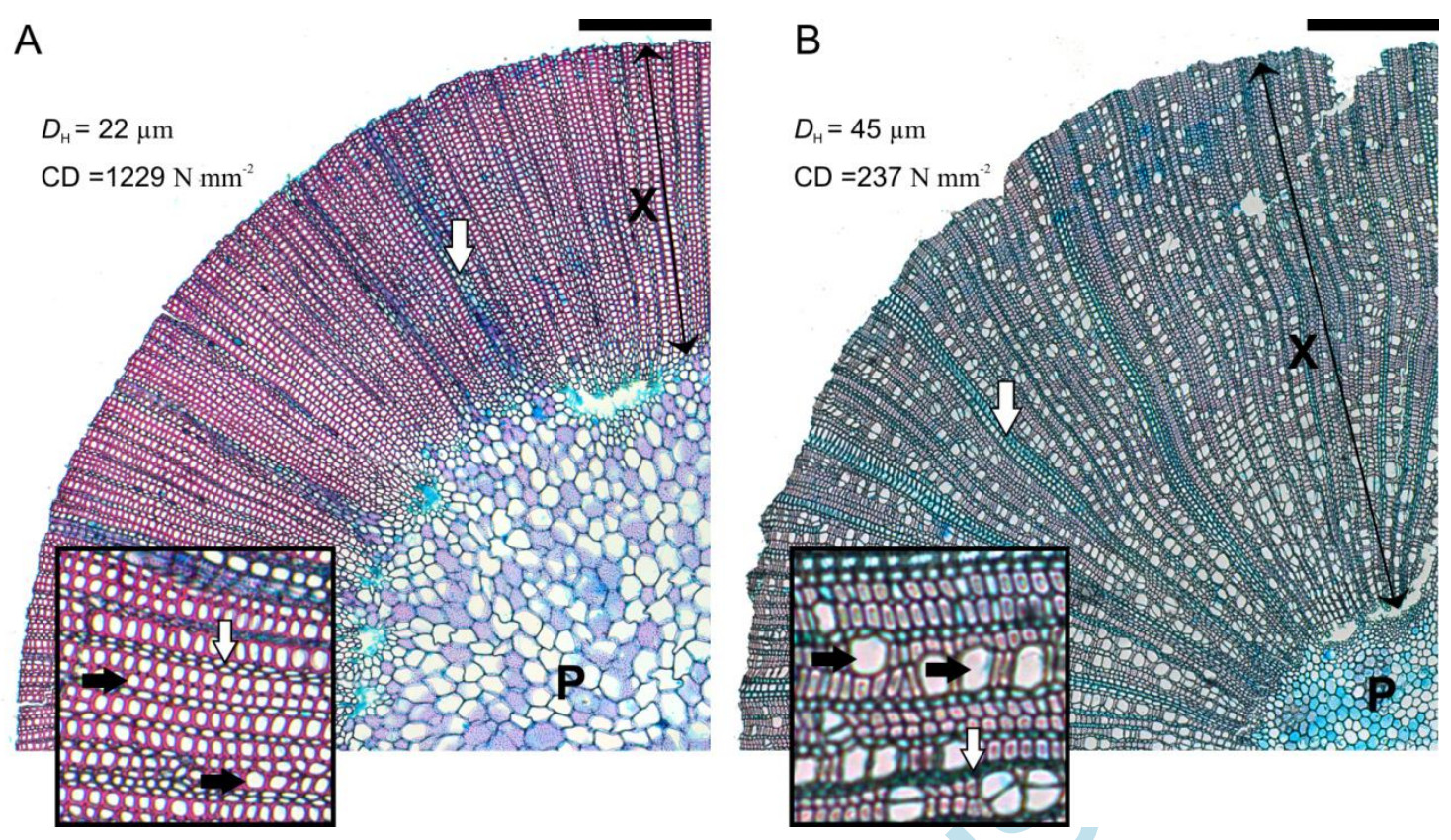

Figure 1. 


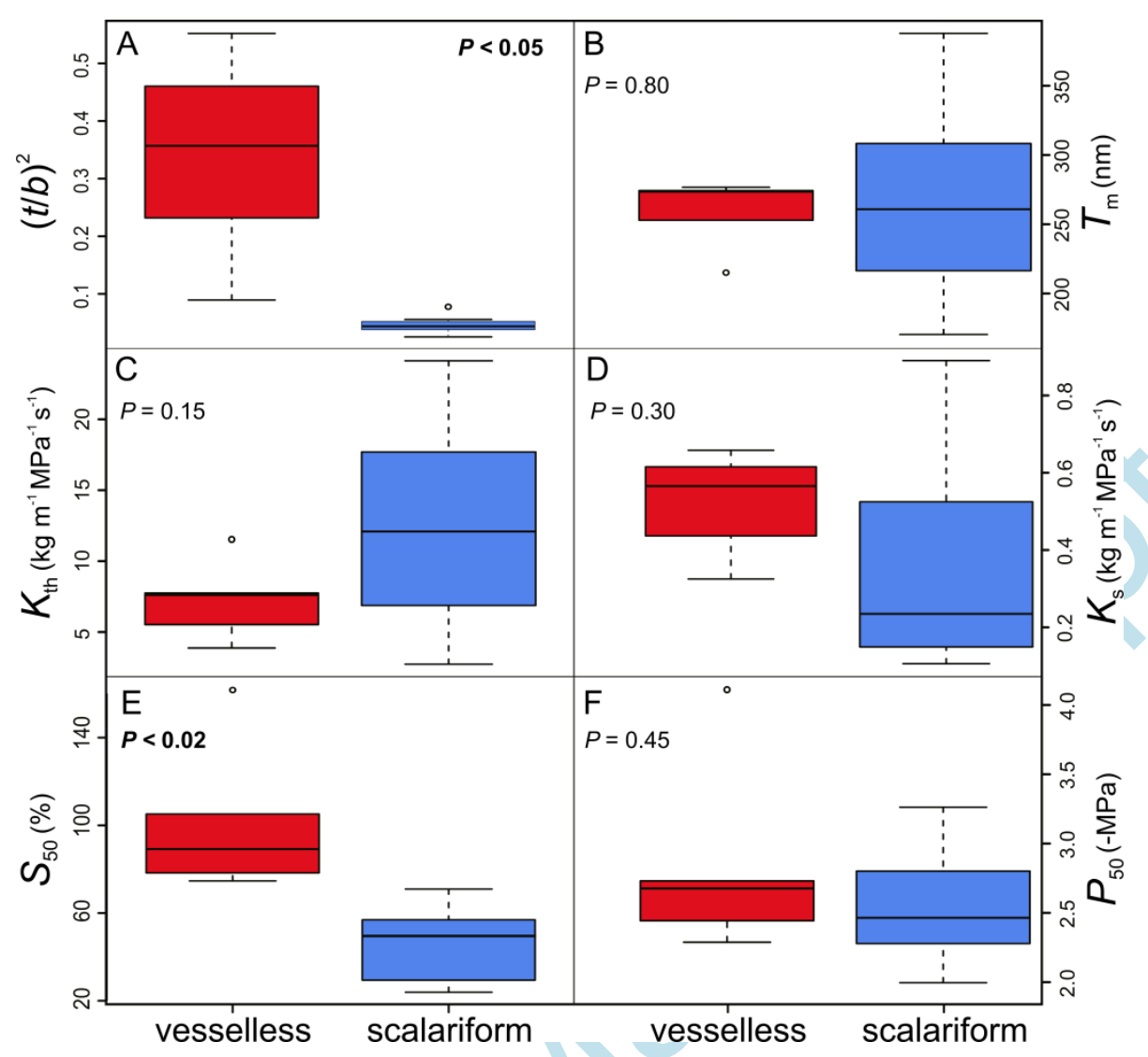

Figure 2. 


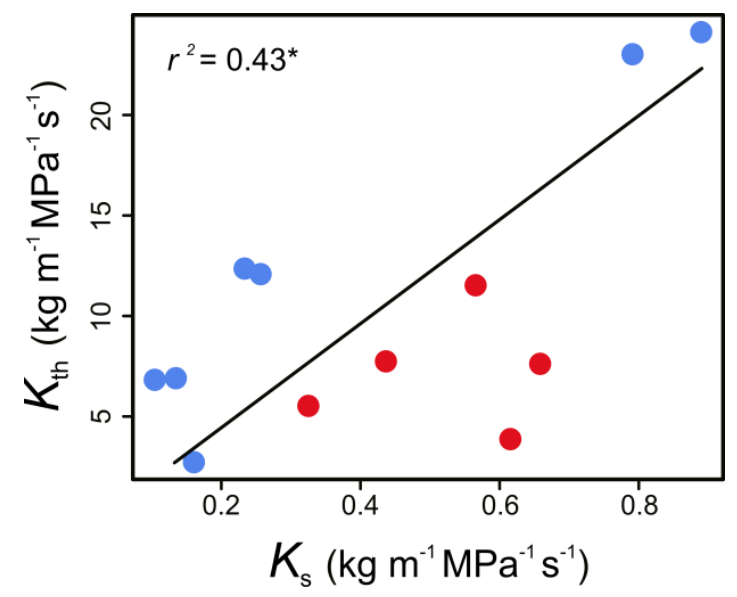

Figure 3. 

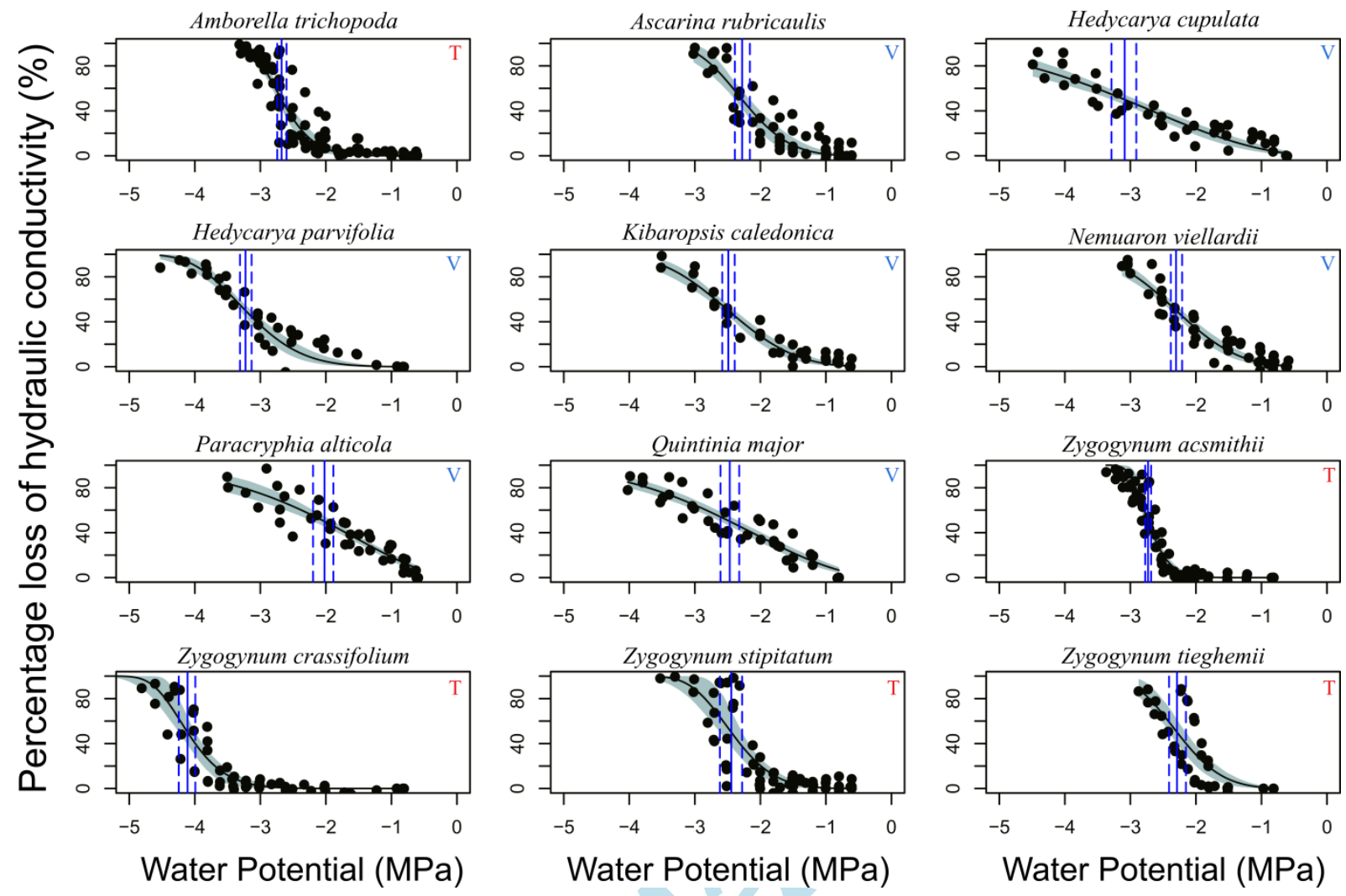

Figure 4. 

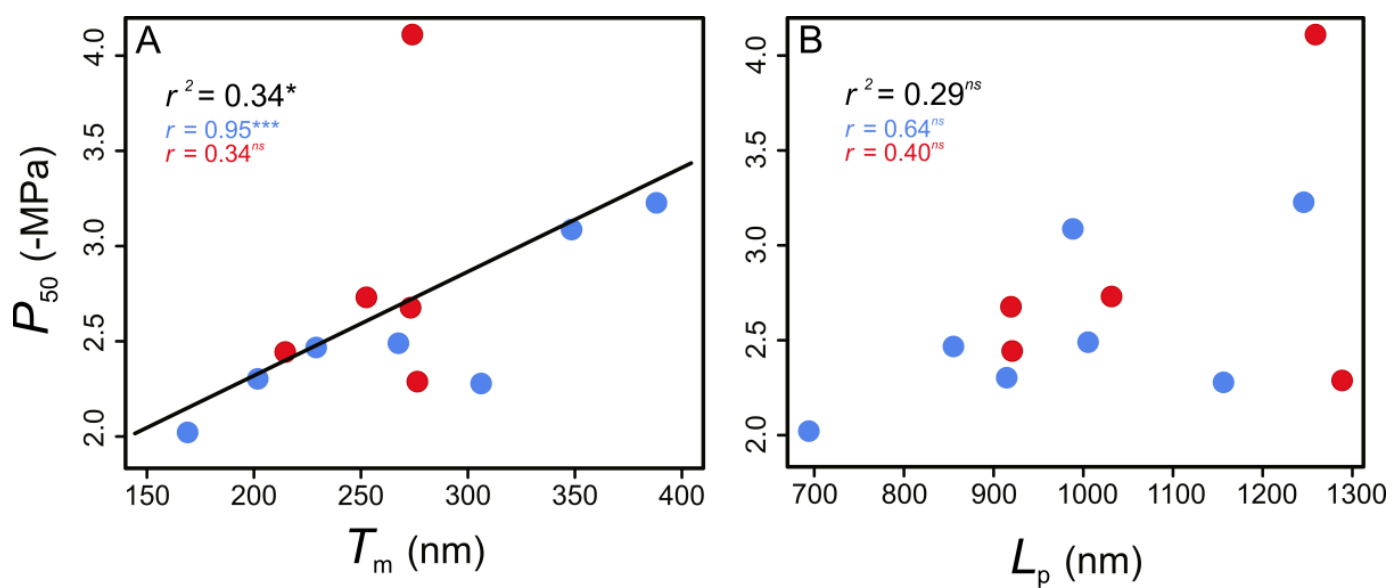

Figure 5. 

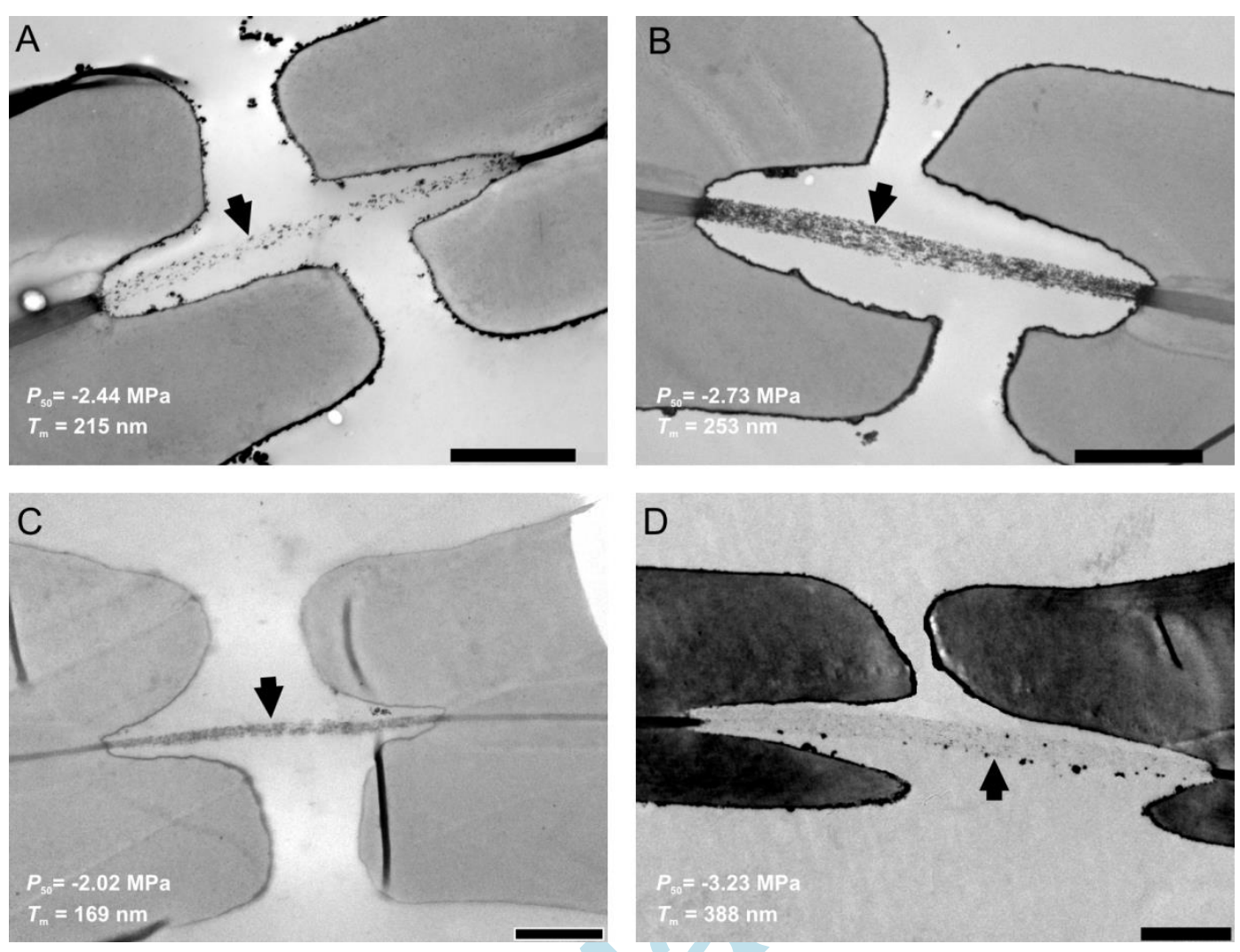

Figure 6. 

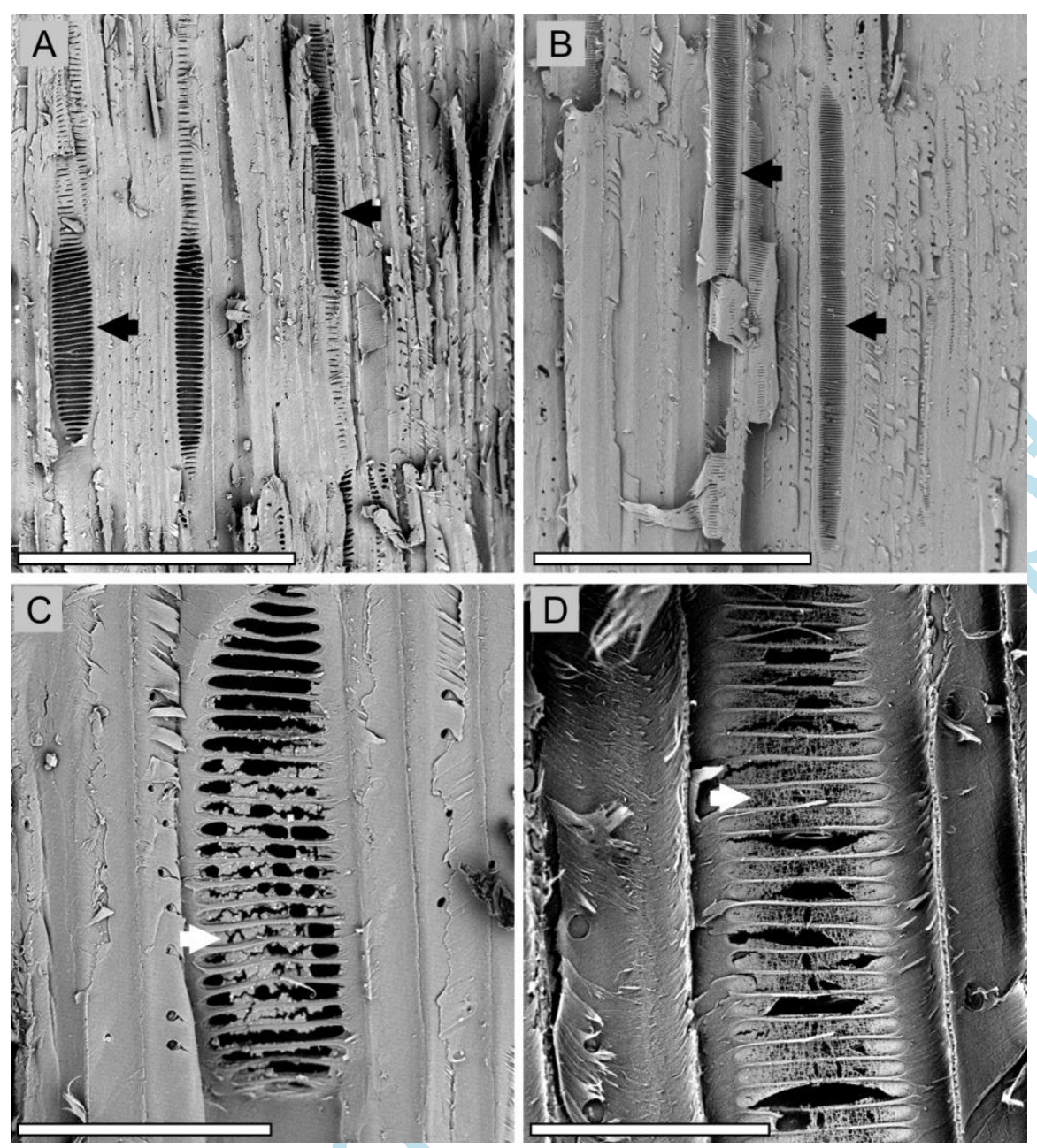

Figure 7. 